\title{
PD-L1 expression by tumor cell-lines: a predictive marker in melanoma
}

Anne C $\mathrm{Knol}^{2}$, Jean-Michel Nguyen ${ }^{2,4}$, Marie-Christine Pandolfino ${ }^{2,3}$, Marc G Denis ${ }^{2,5}$, Amir Khammari $^{1,2}$, Brigitte Dréno ${ }^{1,2,3}$

${ }^{1}$ Service de dermato-cancérologie, CHU Nantes, Nantes, France

${ }^{2}$ Centre de recherche en Cancérologie et Immunologie Nantes-Angers [CRCINA], Institut National de la Santé et de la Recherche Médicale [INSERM] INSERM1232, Université de Nantes, Université d'Angers, CHU Nantes, Nantes, France

${ }^{3}$ Unité de Thérapie Cellulaire et Génique [UTCG], CHU Nantes, Nantes, France

${ }^{4}$ Saint Jacques University Hospital, Service d'évaluation médicale et économique [SEME] Pôle Hospitalo-Universitaire 11 [PHU11], CHU Nantes, Nantes, France

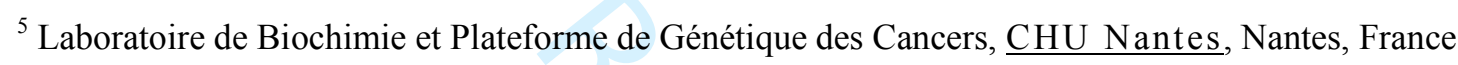

$(\bowtie)$ Corresponding author: Brigitte Dréno, Service de dermato-cancérologie, CHU $\underline{\text { Nantes, }} 1$ place Alexis Ricordeau, 44035 Nantes, France

Phone: 0033240083118

Fax: 0033240083117

e-mail : brigitte.dreno@wanadoo.fr

Co-authors email addresses:

aknol@nantes.inserm.fr

jeanmichel.nguyen@chu-nantes.fr

mcpandolfino@chu-nantes.fr

Marc.DENIS@chu-nantes.fr

amir.khammari@chu-nantes.fr

Word count for text only (from the beginning of the Introduction to the end of the conclusions, without references): 2804 words (4000 words max)

Word count for abstract only: 164 words (200 words max)

Number of items: 2 figures +3 tables +7 supplementary tables +2 supplementary figures

Number of references: 41 


\begin{abstract}
$\underline{\text { Prognostic biomarkers for melanoma patients after lymph node resection are of clinical relevance and }}$ could thus enable the identification of patients who therefore would most benefit from adjuvant treatment. The aim of this work was to determine, using an in vitro model, whether immune-related biomarkers such as MHC-class I and II, melanoma associated antigens, IDO1 and PD-L1, could also be relevant to predict the risk of relapse of stage III melanoma patients after lymph node resection. We established tumor cell lines from metastatic lymph nodes of 50 melanoma patients. The expression of investigated biomarkers was determined on untreated and IFN- $\gamma$ treated melanoma cell lines using flow cytometry. Among the selected biomarkers, the IFN- $\gamma$ induced expression of PD-L1 and IDO1 was associated with an increased risk of relapse $(\mathrm{p}=0.0001$ and $\mathrm{p}=0.013$, respectively) and was also

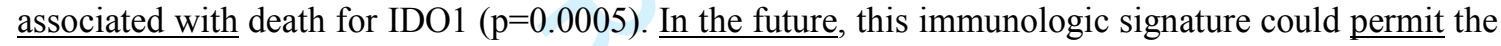
identification of patients at higher risk of relapse, and justifying an adjuvant treatment using immunotherapy.
\end{abstract}

Key words: metastatic melanoma, prognostic markers, survival, melanoma cell-line, flow cytometry 


\begin{abstract}
Abbreviations:
AJCC: American Joint Committee on Cancer

CTA: cancer testis antigens

DNA: desoxyribonucleic acid

GS: gene signature

H\&E: hematoxylin \& eosin

HMW-MAA: high molecular weight-melanoma associated antigen

IDO1: indoleamine 2,3 dioxygenase
\end{abstract}

LN: lymph node

MAA: melanoma associated antigens

mAb: monoclonal antibody

MAGE-A: melanoma-associated antigen-A

MCSP: melanoma chondroitin sulfate proteoglycan

MHC: major histocompatibility complex

NSCLC: non-small cell lung cancer

NY-ESO-1: New York esophageal squamous cell cancer-1

OS: overall survival

P: progression

PCR: polymerase chain reaction

PD-L1: programmed death ligand 1

RC: complete response

RECIST: response evaluation criteria in solid tumor

RFS: relapse free survival

RP: partial response

SSM: superficial spreading melanoma

St: stabilization

TRP2: tyrosinase related protein 2 


\section{Introduction}

Malignant melanoma is the most aggressive cutaneous malignancy with 132,000 new cases occurring worldwide each year (World Health Organization, Skin Cancers) and an annual 3-7\% increase in the incidence rate for Caucasians [1].

Despite the therapeutic revolution brought by innovative treatments such as targeted therapies (BRAF inhibitors), or immune checkpoint inhibitors (i.e. PD-1/PD-L1 or CTLA-4/B7 antibodies), the identification of biomarkers capable of predicting patient prognosis after lymph node resection are still of clinical relevance. Furthermore, new treatments are arriving in the adjuvant setting for stage III melanoma, increasing the interest to select patients with higher risk of relapse [2].

Consequently, attention has been focused on finding biomarkers to identify patients most likely to respond to a specific cancer therapy. Thus, tumor gene expression profiling is a powerful technique for identifying prognostic gene signatures (GSs) [3,4]. Predictive GSs have also been reported in colorectal [5] and gastric cancers [6]. Moreover, both prognostic and predictive GSs have been identified in non-small cell lung cancer (NSCLC) and breast cancer $[7,8]$.

Recently, a 84-gene GS associated with clinical response to MAGE-protein immunizations has been identified in metastatic melanoma [9]. These results were confirmed in resected NSCLC [10]. It was the evidence that clinical response resulting from a cancer immunotherapeutic treatment may be associated with an immune biomarker signature in two different settings (metastatic and adjuvant) and in two tumor types (melanoma and NSCLC). The genes differentially expressed were genes involved in antigen processing, MHC-class I and II, T-cell markers such as CD3 and CD8 and chemokines such as CCL5, CXCL9 and CXCL10.

Meanwhile, a 46-gene GS with strong overrepresentation of immune response genes was identified in 79 stage III melanoma patients, suggesting that BRAF mutation, NRAS mutation, and the absence of an immune-related expressed gene profile predicted poor outcome in stage III melanoma patients [11].

The genes differentially expressed were CCL5, CXCL9, CXCL10, MHC-class II, MAGE-C2, CD2, CD3 and CD8. 
The aim of this work was to assess whether modulation of some biomarkers expressed by melanoma cell-lines, obtained from metastatic regional lymph nodes (LN) and exposed to IFN- $\gamma$, could be an in vitro prognostic tool useful to identify stage III melanoma patients with a higher risk of relapse and a shorter overall survival. For this purpose we analyzed expression of some immune-related biomarkers (MHC-class I and II) and melanoma associated antigens. We also tested expression of PD-L1 and IDO1, two biomarkers known to be modulated by IFN- $\gamma$ and recently identified as enabling melanoma cells to escape immune destruction despite antitumor responses [12-15]. 


\section{Materials and methods}

\section{Melanoma patients}

A total of 50 stage IIIb (AJCC 2007) melanoma patients were included in this study (table 1). For each patient, a melanoma cell-line was obtained from a fragment of a metastatic lymph node (LN). Written informed consent was provided by all patients and the study was approved by the Ethics Committee of Pays de La Loire and Health Authorities (France). The 1964 Declaration of Helsinki protocols and its later amendments or comparable ethical standards were applied in the present study.

\section{Establishment of melanoma cell-lines}

Melanoma cell-lines were established for the 50 tumor samples as previously described by us [16] [17] and by others [18]. Briefly, fresh tumor samples were minced into small tumor pieces in wells of 24well plates (NUNC) with RPMI medium supplemented with $10 \%$ fetal calf serum (FCS). Plates were placed at $37^{\circ} \mathrm{C}$ in a humidified incubator with $5 \% \mathrm{CO}_{2}$ and observed under a light microscope every week and sub-cultured when necessary.

\section{Experiments on melanoma cell lines}

For each cell-line, a total of 500000 cells per well of a 6 -well plate were seeded in $3 \mathrm{ml}$ of culture medium with or without 500U/ml recombinant IFN- $\gamma$ (Tebu, Le Perray en Yvelines, France), in duplicate. After 48 hours of incubation, cells were washed, detached from the wells using PBS-EDTA (Lonza, Levallois, France) and processed for flow cytometry.

\section{Antibodies and flow cytometry}

For membranous staining, $0.2 \times 10^{6}$ cells were stained for 30 minutes at $4^{\circ} \mathrm{C}$ protected from light according to manufacturer's instructions with mouse anti-human MCSP (melanoma chondroitin sulfate proteoglycan) (Miltenyi Biotec, \#130-091-252, dilution 1/40, Bergisch Gladbach, Germany), mouse anti-human B7H1 (PD-L1) (ebioscience, \#12-5983-73, dilution 1/10), HLA-I primary antibody recognizing HLA-A, -B, -C or HLA-II primary antibody recognizing HLA-DP, -DQ, -DR (BD 
Biosciences, respectively \#555551 and \#555557, dilution 1/100, Le Pont de Claix, France) as previously described [19].

For intracellular staining, $0.2 \times 10^{6}$ cells were rinsed twice in DPBS, permeabilized using fixation/permeabilization buffer set (eBioscience, \#00-8333-56, Paris, France) according to the manufacturer's instructions and stained with mouse anti-MAGE-A (melanoma-associated antigen-A) (Tebu, \#sc-20034, dilution 1/40, recommended for detection of MAGE-A1, 2,3, 4, 6, 10 and 12), mouse anti-NY-ESO-1 (New York esophageal squamous cell cancer-1) (Tebu, \#sc-53869, 1/40), mouse anti-tyrosinase (Tebu, \#sc-20035, 1/40), mouse anti-Melan-A (Tebu, \#sc-20032, 1/40) or mouse anti-gp100 (Tebu, \#sc-59305, 1/40) Abs for 30 minutes at $4^{\circ} \mathrm{C}$, or with mouse anti-human IDO1 mAb (Bio-Rad AbD Serotec, \#OBT2037G, dilution 1/200) as previously described [19].

Melanoma cell-lines were gated according to their forward and size scatter characteristics. A minimum of $10^{4}$ viable cell gated events were acquired on a FACScalibur flow cytometer and data were analyzed using the Cell Quest Pro software (Becton Dickinson, Grenoble, France). A 10\% increase of the proportion of tumor cells stained with a given antibody after IFN- $\gamma$ treatment compared to the proportion of tumor cells before IFN- $\gamma$ treatment was considered as a significant increase, a $10 \%$ decrease in this proportion as a significant decrease. A difference comprised between $-5 \%$ and $-10 \%$ in $\underline{\text { the expression of a given biomarker after IFN- } \gamma \text { treatment compared to before IFN- } \gamma \text { treatment was }}$ $\underline{\text { considered as a moderate decrease. }}$

\section{Statistical analysis}

Each biomarker was assessed on melanoma cell-lines with and without IFN- $\gamma$ stimulation.

Cox models were developed for both situations: biomarkers only from treated melanoma cell-lines and biomarkers only from untreated melanoma cell-lines. All models were adjusted on clinico-pathological informations such as the Breslow index, capsular breaking, and number of invaded nodes, BRAF and NRAS mutations. For these 2 situations, the outcome was the impact of biomarkers on patient relapsefree survival (RFS) and overall survival (OS). RFS was calculated as the time interval between lymphadenectomy and the relapse or death and OS was calculated as the time interval between 
lymphadenectomy and the death whatever the cause. Regarding RFS, if death was caused by melanoma, relapse has occurred earlier and if death is not from melanoma, it is considered as a censoring event. Regarding OS, both deaths from melanoma and from another cause were considered. Multivariate Cox model was developed including all biomarkers and clinic-pathological informations such as the Breslow index, capsular breaking, and number of invaded nodes, BRAF and NRAS mutations. The variable selection method of the multivariate model was based on the Akaike Information Criterion [Akaike H. A new look at the statistical model identification. IEEE Trans Automat Contr 1974; 19: 716-723] (AIC). The threshold of significance was set at 5\% in bilateral situation. The R 3.11 statistical software was used for all analyses. All quantitative data were scaled. 


\section{Results}

A total of 50 stage IIIb (AJCC 2007) melanoma patients were included in this study. The main clinical features of these patients are summarized in table 1 and detailed clinical characteristics of the 50 patients are summarized in table 2. Mean age was $51.9 \pm 11.6$ years (median: 53 ; min.-max.:27-72), with 35 men and 15 women. Median event-free survival was 8 months and median survival was 19.5 months.

\section{Expression levels of selected biomarkers by untreated and IFN- $\gamma$ treated melanoma cell-lines}

No untreated melanoma cells expressed PD-L1 (median 0.36\% positive cells) and most untreated melanoma cells did not express IDO1 (median 37\% positive cells); this expression was greatly induced in vitro by IFN- $\gamma$ (median $76.1 \%$ positive cells for PD-L1 and $56 \%$ for IDO1) (figure 1 and 2 , table 3 and supplementary table 1$).$

Most untreated melanoma cells expressed MCSP, gp100, Melan-A and tyrosinase and also MHC-class $\underline{\text { I and MHC-class II antigens (table } 3 \text { and supplementary table 1). Upon IFN- } \gamma \text { treatment, MHC-class II }}$ expression was increased, whereas MCSP and MHC-class I expression was not modified and gp100, $\underline{\text { Melan-A and tyrosinase expression was moderately decreased (table } 3 \text { and supplementary table 1). }}$ $\underline{\text { Half of untreated melanoma cells expressed NY-ESO-1 and MAGE-A antigens and their expression }}$ was decreased upon IFN- $\gamma$ in vitro stimulation (table 3 and supplementary table 1).

\section{Significant associations between selected biomarkers and RFS Univariate analysis}

None of the clinical features was significantly associated with RFS (for Kaplan Meier curves, see supplementary figure 1). No relationship was observed between the 10 selected biomarkers in $\underline{\text { untreated melanoma cell-lines and RFS except for MAGE-A expression }(\mathrm{p}=0.021) \text { and also no }}$ relationship between biomarkers in IFN- $\gamma$ treated melanoma cell-lines and RFS except for tyrosinase $(\mathrm{p}=0.012)$ (supplementary table 2 and supplementary figure 1 for Kaplan Meier curves). 


\section{Multivariate analysis}

Biomarkers in untreated melanoma cell-lines

The expression of MCSP in untreated melanoma cell-lines was associated with an improved RFS $(p=0.026)$ (supplementary table 3$)$. The other biomarkers were not significantly associated with RFS. Biomarkers in IFN- $\gamma$ treated melanoma cell-lines

The induction of PD-L1 and IDO1 expression in IFN- $\gamma$ treated cell-lines was significantly associated with a decreased RFS (respectively $\mathrm{p}=0.0001$ and $\mathrm{p}=0.013$ ) (supplementary table 4). Regarding melanoma associated antigens (MAA), the decreased expression of tyrosinase in IFN- $\gamma$ treated celllines was associated with an improved RFS ( $p=0.0013)$, whereas the decreased expression of NY-

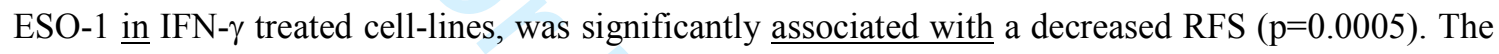
unmodified expression of MCSP upon IFN- $\gamma$ stimulation was associated with an improved RFS $(\mathrm{p}=0.01)$. The other biomarkers were not significantly associated with RFS.

\section{Other clinico-biological markers}

NRAS mutation status was associated with an improved RFS ( $\mathrm{p}=0.0015)$ (supplementary table 4$)$. The number of invaded LNs was significantly associated with a poor RFS ( $\mathrm{p}=0.0175)$. The other clinical markers were not significantly associated with RFS.

\section{Significant associations between selected biomarkers and OS}

\section{Univariate analysis}

We observed that none of the clinical features was significantly associated with OS (for Kaplan Meier curves, see supplementary figure 2). No relationship was observed between the 10 selected biomarkers in untreated melanoma cell-lines and OS except for MAGE-A and NY-ESO-1 (respectively $p=0.0073$ and $\mathrm{p}=0.044)$. In addition, no relationship was identified between these biomarkers in IFN- $\gamma$ treated melanoma cell-lines and OS (supplementary table 5 and supplementary figure 2 for Kaplan Meier curves).

\section{Multivariate analysis}

Biomarkers in untreated melanoma cell-lines 
The expression of tyrosinase was associated with an improved OS ( $\mathrm{p}=0.003)$ (supplementary table 6). The other biomarkers were not significantly associated with OS.

\section{Biomarkers in IFN- $\gamma$ treated melanoma cell-lines}

The induction of IDO1 expression by IFN- $\gamma$ was significantly associated with a decreased OS $(p=0.0005)$ (supplementary table 7). The decreased expression of gp100 and MAGE-A by IFN- $\gamma$ was associated with an improved OS (respectively $\mathrm{p}=0.007$ and $\mathrm{p}=0.023$ ) whereas the decreased expression of Melan-A by IFN- $\gamma$ was significantly associated with a decreased OS $(p=0.028)$. The unmodified expression of MCSP upon IFN- $\gamma$ stimulation was associated with an improved OS $(\mathrm{p}=0.02)$. The other biomarkers were not significantly associated with OS.

Other clinico-biological markers

High Breslow index and capsular breaking were significantly associated with a poor OS (respectively $\mathrm{p}=0.03$ and $\mathrm{p}=0.0026$ ) (supplementary table 7 ). The other clinical markers were not significantly associated with OS. 


\section{Discussion}

In the present work, we conducted a multivariate analysis of clinical and pathological determinants of outcome and several immune-related biomarkers, melanoma associated antigens, and two important biomarkers of immune relevance in melanoma: IDO1 and PD-L1.

First, we observed that most untreated melanoma cell-lines did not express IDO1. Moreover, the induction of IDO1 expression by IFN- $\gamma$ treatment was significantly associated with both decreased RFS and OS, making IDO1 the only biomarker associated with both RFS and OS in this study. IDO1 is an intra-cellular enzyme that degrades tryptophan to kynurenine, inducing a local immunosuppression through deficiency in this essential amino acid, which is needed for the activity of T-cells $[20]$. There is evidence that IFN- $\gamma$ stimulates IDO1 gene transcription in many cell types $[21,22]$. In melanoma, IDO1 has been shown to be increased in both primary and metastatic lesions and its expression correlated with increased invasiveness and disease relapse rate $[12,13]$. We recently reported an induction of PD-L1 expression by melanoma cells when co-cultivated with IDO1 expressing fetal fibroblasts [23]. We assumed that this induction of PD-L1 by IDO1 may contribute to inhibit the efficacy of adoptive cell therapy using TILs, by inducing inactivation of lymphocytes, decreasing both their survival and proliferation. This way, IDO1 appears as a molecule that may play a major role in immune tolerance induction, in melanoma microenvironment.

We also observed that untreated melanoma cells did not express PD-L1. Interestingly, the induced expression of PD-L1 in IFN- $\gamma$ treated cell-lines was significantly associated with a decreased RFS. It is well known that many malignant cells express PD-L1, either constitutively or after IFN$\gamma$ induction [24,25]. PD-L1 expression has been described as having multiple prognostic significances, depending on the tumor type. It has been correlated with decreased survival in ovarian, pancreatic, and renal cell carcinomas [26-28], and has been associated with an improved survival in patients with Merkel cell [29], breast [30], and cervical carcinomas [31]. Conflicting reports also exist regarding its significance in melanoma $[14,15]$. However, all these studies were conducted on tumor tissue samples and not on in vitro tumor cell-lines. 
$\underline{\text { Regarding melanoma associated antigens (MAA), gp100/PMEL, Melan-A/MART-1 and tyrosinase, }}$ we observed that their expression was moderately decreased upon IFN- $\gamma$ treatment of melanoma cell$\underline{\text { lines. Variable responses after IFN stimulation on MAA expression had already been reported in the }}$ literature, ranging from moderate induction to suppression [32]. Moreover, upon IFN- $\gamma$ stimulation, we observed that the decreased expression of tyrosinase was associated with an improved RFS and the decreased expression of gp 100 to an improved OS whereas the decreased expression of Melan-A was associated with a decreased OS. Our conflicting results regarding the predictive value of MAA perfectly illustrates the fact that data on this subject are controversial [33-35]. Finally, we report that the unmodified MCSP expression in IFN- $\gamma$ treated melanoma cell-lines was related to both increased RFS and OS. MCSP/HMW-MAA is highly expressed in more than $85 \%$ of melanomas [36] and is thought to contribute to the malignant phenotype of melanoma cells via enhancement of their spreading, invasion, and migration [37]. To our knowledge, no data exist to date regarding the predictive or prognostic value of MCSP expression level in melanoma.

Regarding cancer testis antigens (CTA), we observed here that the decreased expression of MAGE-A was associated with an improved OS, whereas the decreased expression of NY-ESO-1 was associated with a diminished RFS. This result is consistent with our previous study reporting that the expression of MAGE-A1 and MAGE-A3 but in contradiction for NY-ESO-1 which was significantly associated with a higher RFS in stage III melanoma patients [38]. However in the present work we used flow cytometry to determine the expression level of tumor associated antigens on melanoma cell-lines, whereas in our work published in 2009, we used a semi-quantitative RT-PCR analysis on melanoma $\underline{\text { tissue specimens. In primary cutaneous melanoma, Svobodova et al reported that the median RFS of }}$ patients with the three CTA (MAGE-A1, MAGE-A4 and NY-ESO-1) positive tumors was significantly reduced compared to those of patients with CTA-negative tumors [39].

We finally observed that NRAS mutation status was associated with an improved RFS. However, controversial data exist in the literature on this subject. For instance, Ekedahl et al observed a trend showing a better prognosis for patients with NRAS-mutant tumors compared with BRAF V600E- 
mutant tumors [40], although other studies reported an association between NRAS mutation and worse prognosis in stage IV melanoma [41] but also in stage III melanoma [11].

One of the limitations of our work is that it is not always possible to obtain melanoma cell-lines and the delay for obtaining it. In our experience, we managed to obtain cell-lines for $80 \%$ of our patients. The median time necessary to obtain the cell-lines was 2 months after complete lymph node resection. This is not so long as compared to inclusion in a clinical trial. Furthermore, the adjuvant treatment could be initiated before obtaining the cell line, and changed when the data become available.

$\underline{\text { In conclusion, our results suggest that it is possible to identify a dynamic prognostic immunological }}$ profile of melanoma cells, for stage III melanoma patients with lymph node involvement. Melanoma cell-lines treated with IFN- $\gamma$ could be an interesting tool to identify stage III melanoma patients with a higher risk of relapse. Thus, we propose that the modulation of PD-L1 and IDO1 expression in melanoma cell-lines incubated with IFN- $\gamma$ could help screening patients most at risk of relapse and shorter overall survival. These biomarkers have a prognostic value on RFS and OS. In the future, this immunological profile of melanoma cells could help to identify stage III melanoma patients with a higher risk of relapse and thus justifying an adjuvant treatment. Today, this last point is highly relevant because of new treatments costs, but also adverse events occurrence, that can persist despite stopping $\underline{\text { treatment. }}$ 


\section{Acknowledgements}

We gratefully acknowledge GlaxoSmithKline Biologicals SA for their financial support.

We thank Emilie Varey (RIC-Mel network) for her helpful assistance in collecting clinical data.

We also thank the cytometry facility Cytocell for their expert technical assistance.

\section{Funding Support}

This study was funded by GlaxoSmithKline Biologicals SA.

\section{Conflict of interest}

The authors declare that they have no conflict of interest.

\section{Author contributions}

AC Knol and MC Pandolfino performed experiments

AC Knol, A.Khammari and B.Dréno conceived and designed the research study

A.Khammari and MG Denis contributed essential reagents/materials/analysis tools

AC Knol, MC Pandolfino P and JM Nguyen analysed the data

AC Knol and B.Dréno wrote the paper

All authors reviewed and commented critically drafts of the manuscript for important intellectual content and gave final approval to submit for publication. 


\section{References}

1. Parkin DM, Bray F, Ferlay J, Pisani P: Estimating the world cancer burden: Globocan 2000. Int J Cancer 2001;94:153-156.

2. Eggermont AM, Chiarion-Sileni V, Grob JJ, Dummer R, Wolchok JD, Schmidt H, Hamid O, Robert C, Ascierto PA, Richards JM, Lebbe C, Ferraresi V, Smylie M, Weber JS, Maio M, Bastholt L, Mortier L, Thomas L, Tahir S, Hauschild A, Hassel JC, Hodi FS, Taitt C, de Pril V, de Schaetzen G, Suciu S, Testori A: Prolonged Survival in Stage III Melanoma with Ipilimumab Adjuvant Therapy. N Engl J Med 2016;375:1845-1855.

3. Kratz JR, He J, Van Den Eeden SK, Zhu ZH, Gao W, Pham PT, Mulvihill MS, Ziaei F, Zhang H, Su $B$, Zhi X, Quesenberry CP, Habel LA, Deng $Q$, Wang Z, Zhou J, Li H, Huang MC, Yeh CC, Segal MR, Ray MR, Jones KD, Raz DJ, Xu Z, Jahan TM, Berryman D, He B, Mann MJ, Jablons DM: A practical molecular assay to predict survival in resected non-squamous, non-small-cell lung cancer: development and international validation studies. Lancet 2012;379:823-832.

4. van 't Veer LJ, Dai H, van de Vijver MJ, He YD, Hart AA, Mao M, Peterse HL, van der Kooy K, Marton MJ, Witteveen AT, Schreiber GJ, Kerkhoven RM, Roberts C, Linsley PS, Bernards R, Friend SH: Gene expression profiling predicts clinical outcome of breast cancer. Nature 2002;415:530-536.

5. Baker JB, Dutta D, Watson D, Maddala T, Munneke BM, Shak S, Rowinsky EK, Xu LA, Harbison $\mathrm{CT}$, Clark EA, Mauro DJ, Khambata-Ford S: Tumour gene expression predicts response to cetuximab in patients with KRAS wild-type metastatic colorectal cancer. $\mathrm{Br} J$ Cancer 2011;104:488-495.

6. Kim HK, Choi IJ, Kim CG, Kim HS, Oshima A, Yamada Y, Arao T, Nishio K, Michalowski A, Green JE: Three-gene predictor of clinical outcome for gastric cancer patients treated with chemotherapy. Pharmacogenomics J 2012;12:119-127.

7. Albain KS, Barlow WE, Shak S, Hortobagyi GN, Livingston RB, Yeh IT, Ravdin P, Bugarini R, Baehner FL, Davidson NE, Sledge GW, Winer EP, Hudis C, Ingle JN, Perez EA, Pritchard KI, Shepherd L, Gralow JR, Yoshizawa C, Allred DC, Osborne CK, Hayes DF: Prognostic and predictive value of the 21-gene recurrence score assay in postmenopausal women with node-positive, oestrogen-receptor-positive breast cancer on chemotherapy: a retrospective analysis of a randomised trial. Lancet Oncol 2010;11:55-65.

8. Zhu CQ, Ding K, Strumpf D, Weir BA, Meyerson M, Pennell N, Thomas RK, Naoki K, LaddAcosta C, Liu N, Pintilie M, Der S, Seymour L, Jurisica I, Shepherd FA, Tsao MS: Prognostic and predictive gene signature for adjuvant chemotherapy in resected non-small-cell lung cancer. J Clin Oncol 2010;28:4417-4424.

9. Kruit WH, Suciu S, Dreno B, Mortier L, Robert C, Chiarion-Sileni V, Maio M, Testori A, Dorval T, Grob JJ, Becker JC, Spatz A, Eggermont AM, Louahed J, Lehmann FF, Brichard VG, Keilholz $\mathrm{U}$ : Selection of immunostimulant AS15 for active immunization with MAGE-A3 protein: results of a randomized phase II study of the European Organisation for Research and Treatment of Cancer Melanoma Group in Metastatic Melanoma. J Clin Oncol 2013;31:24132420.

10. Ulloa-Montoya F, Louahed J, Dizier B, Gruselle O, Spiessens B, Lehmann FF, Suciu S, Kruit WH, Eggermont AM, Vansteenkiste J, Brichard VG: Predictive gene signature in MAGE-A3 antigenspecific cancer immunotherapy. J Clin Oncol 2013;31:2388-2395.

11. Mann GJ, Pupo GM, Campain AE, Carter CD, Schramm SJ, Pianova S, Gerega SK, De Silva C, Lai K, Wilmott JS, Synnott M, Hersey P, Kefford RF, Thompson JF, Yang YH, Scolyer RA: BRAF mutation, NRAS mutation, and the absence of an immune-related expressed gene profile predict poor outcome in patients with stage III melanoma. J Invest Dermatol 2013;133:509517. 
12. Brody JR, Costantino CL, Berger AC, Sato T, Lisanti MP, Yeo CJ, Emmons RV, Witkiewicz AK: Expression of indoleamine 2,3-dioxygenase in metastatic malignant melanoma recruits regulatory T cells to avoid immune detection and affects survival. Cell Cycle 2009;8:19301934.

13. Chevolet I, Speeckaert R, Haspeslagh M, Neyns B, Kruse V, Schreuer M, Van Gele M, Van Geel $\mathrm{N}$, Brochez L: Peritumoral indoleamine 2,3-dioxygenase expression in melanoma: an early marker of resistance to immune control? Br J Dermatol 2014;171:987-995.

14. Hino R, Kabashima K, Kato Y, Yagi H, Nakamura M, Honjo T, Okazaki T, Tokura Y: Tumor cell expression of programmed cell death-1 ligand 1 is a prognostic factor for malignant melanoma. Cancer 2010;116:1757-1766.

15. Taube JM, Anders RA, Young GD, Xu H, Sharma R, McMiller TL, Chen S, Klein AP, Pardoll DM, Topalian SL, Chen L: Colocalization of inflammatory response with B7-h1 expression in human melanocytic lesions supports an adaptive resistance mechanism of immune escape. Sci Transl Med 2012;4:127ra137.

16. Pandolfino MC, Saiagh S, Knol AC, Dreno B: Comparison of three culture media for the establishment of melanoma cell lines. Cytotechnology 2010;62:403-412.

17. Gervois N, Heuze F, Diez E, Jotereau F: Selective expansion of a specific anti-tumor CD8+ cytotoxic $T$ lymphocyte clone in the bulk culture of tumor-infiltrating lymphocytes from a melanoma patient: cytotoxic activity and T cell receptor gene rearrangements. Eur J Immunol 1990;20:825-831.

18. Halaban R, Ghosh S, Duray P, Kirkwood JM, Lerner AB: Human melanocytes cultured from nevi and melanomas. J Invest Dermatol 1986;87:95-101.

19. Zuliani T, Saiagh S, Knol AC, Esbelin J, Dreno B: Fetal fibroblasts and keratinocytes with immunosuppressive properties for allogeneic cell-based wound therapy. PLoS One 2013;8:e70408.

20. Munn DH, Shafizadeh E, Attwood JT, Bondarev I, Pashine A, Mellor AL: Inhibition of T cell proliferation by macrophage tryptophan catabolism. J Exp Med 1999;189:1363-1372.

21. Mancuso R, Hernis A, Agostini S, Rovaris M, Caputo D, Fuchs D, Clerici M: Indoleamine 2,3 Dioxygenase (IDO) Expression and Activity in Relapsing-Remitting Multiple Sclerosis. PLoS One 2015;10:e0130715.

22. Taylor MW, Feng GS: Relationship between interferon-gamma, indoleamine 2,3-dioxygenase, and tryptophan catabolism. Faseb J 1991;5:2516-2522.

23. Frenard C, Knol AC, Lemoigne M, Khammari A, Dreno B: Effect of indoleamine 2,3dioxygenase expressed by foetal fibroblasts on melanoma cells. Exp Dermatol 2016;25:822824.

24. Chen L: Co-inhibitory molecules of the B7-CD28 family in the control of T-cell immunity. Nat Rev Immunol 2004;4:336-347.

25. Dong H, Strome SE, Salomao DR, Tamura H, Hirano F, Flies DB, Roche PC, Lu J, Zhu G, Tamada $\mathrm{K}$, Lennon VA, Celis E, Chen L: Tumor-associated B7-H1 promotes T-cell apoptosis: a potential mechanism of immune evasion. Nat Med 2002;8:793-800.

26. Giraldo NA, Becht E, Pages F, Skliris G, Verkarre V, Vano Y, Mejean A, Saint-Aubert N, Lacroix L, Natario I, Lupo A, Alifano M, Damotte D, Cazes A, Triebel F, Freeman GJ, Dieu-Nosjean MC, Oudard S, Fridman WH, Sautes-Fridman C: Orchestration and Prognostic Significance of Immune Checkpoints in the Microenvironment of Primary and Metastatic Renal Cell Cancer. Clin Cancer Res 2015;21:3031-3040.

27. Hamanishi J, Mandai M, Iwasaki M, Okazaki T, Tanaka Y, Yamaguchi K, Higuchi T, Yagi H, Takakura K, Minato N, Honjo T, Fujii S: Programmed cell death 1 ligand 1 and tumorinfiltrating CD8+ T lymphocytes are prognostic factors of human ovarian cancer. Proc Natl Acad Sci U S A 2007;104:3360-3365. 
28. Nomi T, Sho M, Akahori T, Hamada K, Kubo A, Kanehiro H, Nakamura S, Enomoto K, Yagita H, Azuma M, Nakajima Y: Clinical significance and therapeutic potential of the programmed death-1 ligand/programmed death-1 pathway in human pancreatic cancer. Clin Cancer Res 2007;13:2151-2157.

29. Lipson EJ, Vincent JG, Loyo M, Kagohara LT, Luber BS, Wang H, Xu H, Nayar SK, Wang TS, Sidransky D, Anders RA, Topalian SL, Taube JM: PD-L1 expression in the Merkel cell carcinoma microenvironment: association with inflammation, Merkel cell polyomavirus and overall survival. Cancer Immunol Res 2013;1:54-63.

30. Wimberly H, Brown JR, Schalper K, Haack H, Silver MR, Nixon C, Bossuyt V, Pusztai L, Lannin DR, Rimm DL: PD-L1 Expression Correlates with Tumor-Infiltrating Lymphocytes and Response to Neoadjuvant Chemotherapy in Breast Cancer. Cancer Immunol Res 2015;3:326332.

31. Karim R, Jordanova ES, Piersma SJ, Kenter GG, Chen L, Boer JM, Melief CJ, van der Burg SH: Tumor-expressed $\mathrm{B} 7-\mathrm{H} 1$ and $\mathrm{B} 7-\mathrm{DC}$ in relation to PD-1+ T-cell infiltration and survival of patients with cervical carcinoma. Clin Cancer Res 2009;15:6341-6347.

32. Hofbauer GF, Geertsen R, Laine E, Burg G, Dummer R: Impact of interferons on the expression of melanoma-associated antigens in melanoma short-term cell cultures. Melanoma Res 2001;11:213-218.

33. de Vries TJ, Smeets M, de Graaf R, Hou-Jensen K, Brocker EB, Renard N, Eggermont AM, van Muijen GN, Ruiter DJ: Expression of gp100, MART-1, tyrosinase, and S100 in paraffinembedded primary melanomas and locoregional, lymph node, and visceral metastases: implications for diagnosis and immunotherapy. A study conducted by the EORTC Melanoma Cooperative Group. J Pathol 2001;193:13-20.

34. Takeuchi H, Kuo C, Morton DL, Wang HJ, Hoon DS: Expression of differentiation melanomaassociated antigen genes is associated with favorable disease outcome in advanced-stage melanomas. Cancer Res 2003;63:441-448.

35. Welinder C, Pawlowski K, Szasz AM, Yakovleva M, Sugihara Y, Malm J, Jonsson G, Ingvar C, Lundgren L, Baldetorp B, Olsson H, Rezeli M, Laurell T, Wieslander E, Marko-Varga G: Correlation of histopathologic characteristics to protein expression and function in malignant melanoma. PLoS One 2017;12:e0176167.

36. Kitago M, Koyanagi K, Nakamura T, Goto Y, Faries M, O'Day SJ, Morton DL, Ferrone S, Hoon DS: mRNA expression and BRAF mutation in circulating melanoma cells isolated from peripheral blood with high molecular weight melanoma-associated antigen-specific monoclonal antibody beads. Clin Chem 2009;55:757-764.

37. Campoli MR, Chang CC, Kageshita T, Wang X, McCarthy JB, Ferrone S: Human high molecular weight-melanoma-associated antigen (HMW-MAA): a melanoma cell surface chondroitin sulfate proteoglycan (MSCP) with biological and clinical significance. Crit Rev Immunol 2004;24:267-296.

38. Vourc'h-Jourdain M, Volteau C, Nguyen JM, Khammari A, Dreno B: Melanoma gene expression and clinical course. Arch Dermatol Res 2009;301:673-679.

39. Svobodova S, Browning J, MacGregor D, Pollara G, Scolyer RA, Murali R, Thompson JF, Deb S, Azad A, Davis ID, Cebon JS: Cancer-testis antigen expression in primary cutaneous melanoma has independent prognostic value comparable to that of Breslow thickness, ulceration and mitotic rate. Eur J Cancer 2010;47:460-469.

40. Ekedahl H, Cirenajwis H, Harbst K, Carneiro A, Nielsen K, Olsson H, Lundgren L, Ingvar C, Jonsson G: The clinical significance of BRAF and NRAS mutations in a clinic-based metastatic melanoma cohort. Br J Dermatol 2013;169:1049-1055.

41. Jakob JA, Bassett RL, Jr., Ng CS, Curry JL, Joseph RW, Alvarado GC, Rohlfs ML, Richard J, Gershenwald JE, Kim KB, Lazar AJ, Hwu P, Davies MA: NRAS mutation status is an independent prognostic factor in metastatic melanoma. Cancer 2012;118:4014-4023. 
Page 22 of 32

19

$$
\begin{aligned}
& 1 \\
& 2 \\
& 3 \\
& 4 \\
& 5 \\
& 6 \\
& 7 \\
& 8 \\
& 9 \\
& 10 \\
& 11 \\
& 12 \\
& 13 \\
& 14 \\
& 15 \\
& 16 \\
& 17 \\
& 18 \\
& 19 \\
& 20 \\
& 21 \\
& 22 \\
& 23 \\
& 24 \\
& 25 \\
& 26 \\
& 27 \\
& 28 \\
& 29 \\
& 30 \\
& 31 \\
& 32 \\
& 33 \\
& 34 \\
& 35 \\
& 36 \\
& 37 \\
& 38 \\
& 39 \\
& 40 \\
& 41 \\
& 42 \\
& 43 \\
& 44 \\
& 45 \\
& 46 \\
& 47 \\
& 48 \\
& 49 \\
& 50 \\
& 51 \\
& 52 \\
& 53 \\
& 54 \\
& 55 \\
& 56 \\
& 57 \\
& 59
\end{aligned}
$$


Table 1: Main clinico-pathological features of the 50 melanoma patients Variable Overall population (50)

Age (years)

51,9 years $(+/-11,6)$

$\geq 50$ years
$<50$ years

10

Adjuvant treatment

$$
\begin{array}{r}
\text { TILs + IL-2 } \\
\text { IFN-alpha } \\
\text { IL-2 } \\
\text { None }
\end{array}
$$

Breslow

$<1,5 \mathrm{~mm}$

$>1,5 \mathrm{~mm}$

Missing data

\section{Ulceration}

Capsular breaking
Yes
No

Missing data

Mean progression free survival

Mean overall survival

Mutations 
Table 3: Median expression of selected biomarkers by untreated melanoma cell-lines and IFN- $\gamma$ stimulated melanoma cell-lines

\begin{tabular}{|c|c|c|}
\cline { 2 - 3 } \multicolumn{1}{c|}{} & $\begin{array}{c}\text { untreated } \\
\text { melanoma } \\
\text { cells }\end{array}$ & $\begin{array}{c}\text { IFN- } \gamma \\
\text { treated } \\
\text { melanoma } \\
\text { cells }\end{array}$ \\
\hline PD-L1 & $0,4 \%$ & $76,1 \%$ \\
\hline IDO1 & $37,0 \%$ & $56,1 \%$ \\
\hline MHC-I & $90,2 \%$ & $84,3 \%$ \\
\hline MHC-II & $67,7 \%$ & $79,8 \%$ \\
\hline gp100 & $68,5 \%$ & $63,3 \%$ \\
\hline Melan-A & $74,5 \%$ & $65,8 \%$ \\
\hline tyrosinase & $74,5 \%$ & $58,2 \%$ \\
\hline NY-ESO-1 & $52,5 \%$ & $37,9 \%$ \\
\hline MAGE-A & $43,0 \%$ & $26,8 \%$ \\
\hline MCSP & $91,3 \%$ & $88,6 \%$ \\
\hline
\end{tabular}

Figure 1: Median expression of PD-L1 and IDO1 in untreated melanoma cell-lines and IFN- $\gamma$ stimulated melanoma cell-lines

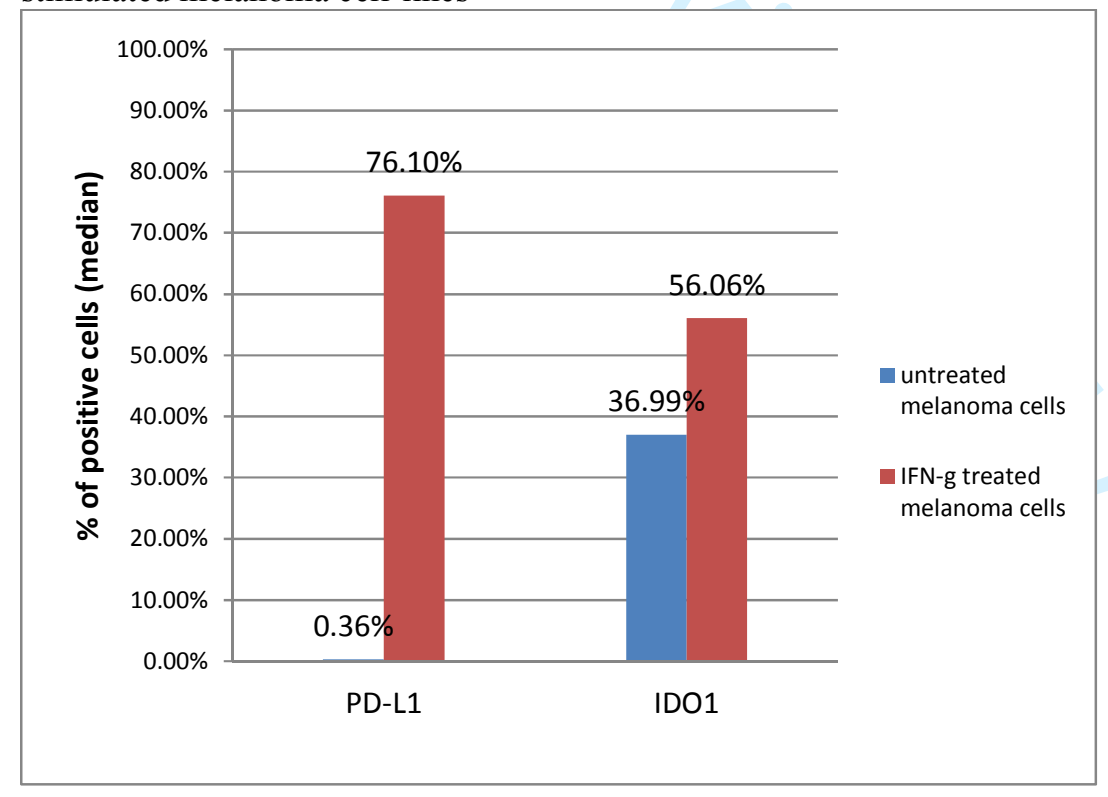


Page 25 of 32

22

$$
\begin{aligned}
& 1 \\
& 2 \\
& 3 \\
& 4 \\
& 5 \\
& 6 \\
& 7 \\
& 8 \\
& 9 \\
& 10 \\
& 11 \\
& 12 \\
& 13 \\
& 14 \\
& 15 \\
& 16 \\
& 17 \\
& 18 \\
& 19 \\
& 20 \\
& 21 \\
& 22 \\
& 23 \\
& 24 \\
& 25 \\
& 26 \\
& 27 \\
& 28 \\
& 29 \\
& 30 \\
& 31 \\
& 32 \\
& 33 \\
& 34 \\
& 35 \\
& 36 \\
& 37 \\
& 38 \\
& 39 \\
& 40 \\
& 41 \\
& 42 \\
& 43 \\
& 44 \\
& 45 \\
& 46 \\
& 47 \\
& 48 \\
& 49 \\
& 50 \\
& 51 \\
& 52 \\
& 53 \\
& 54 \\
& 55 \\
& 56 \\
& 57 \\
& 58 \\
& 59 \\
& 60
\end{aligned}
$$

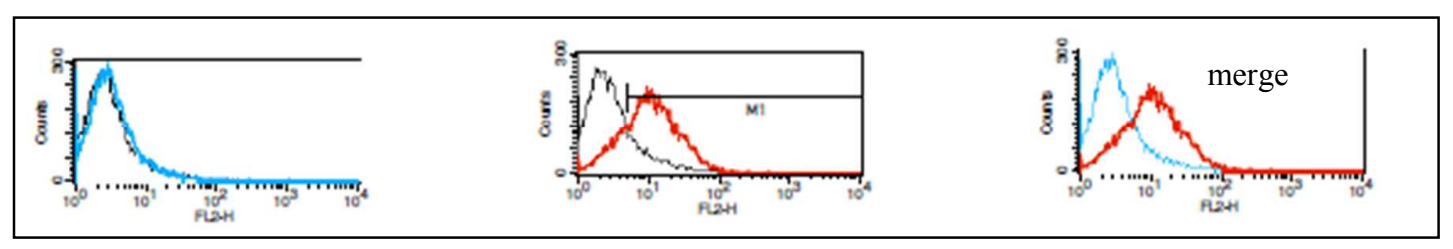

2A Membranous PD-L1 expression

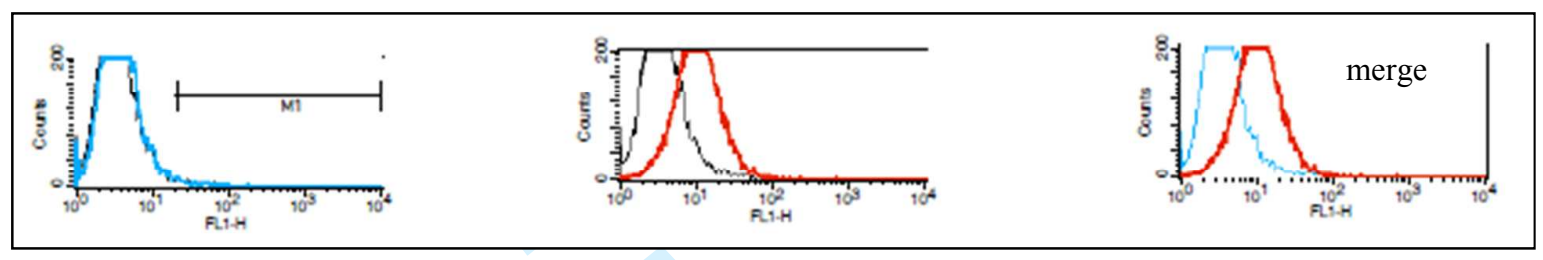

2B Intracellular IDO1 expression 


\section{Figure legends}

Figure 1: Median expression of PD-L1 and IDO1 in untreated melanoma cell-lines and IFN- $\gamma$ stimulated melanoma cell-lines

Figure 2: Representative pictures of flow cytometric analyses for PD-L1 (2A) and IDO1 (2B)

Blue line: untreated melanoma cells, red line: IFN- $\gamma$ treated melanoma cells, black line: isotypic control

Supplementary figure 1: Kaplan Meier curves for RFS

Supplementary figure 2: Kaplan Meier curves for OS

Table 1: Main clinico-pathological features of the 50 melanoma patients

Table 2: Detailed clinico-biological characteristics of the 50 melanoma patients

Table 3: Median expression of selected biomarkers in untreated melanoma cell-lines and IFN- $\gamma$ stimulated melanoma cell-lines

Supplementary table 1: Cytometric analysis of the 50 melanoma cell-lines (data are expressed as \% of positive cells)

Supplementary table 2: Univariate model for RFS including biomarkers from both untreated and IFN- $\gamma$ treated melanoma cell-lines

Supplementary table 3: Cox model for RFS including only biomarkers from untreated melanoma celllines

Supplementary table 4: Cox model for RFS including only biomarkers from IFN- $\gamma$ treated melanoma cell-lines

Supplementary table 5: Univariate model for OS including biomarkers from both untreated and IFN- $\gamma$ treated melanoma cell-lines

Supplementary table 6: Cox model for OS including only biomarkers from untreated melanoma celllines

Supplementary table 7: Cox model for OS including only biomarkers from IFN- $\gamma$ treated melanoma cell-lines 


\section{Page 27 of 32}

\begin{tabular}{|c|c|c|c|c|c|c|c|c|c|c|c|c|c|c|c|c|c|c|c|c|c|c|c|}
\hline 1 & $\begin{array}{l}\text { Patients } \\
\text { code }\end{array}$ & Stage & $\begin{array}{l}\text { BRAFNNRAS } \\
\text { mutation testing } \\
\text { FFPE tumor } \\
\text { sample }\end{array}$ & $\begin{array}{l}\text { \% tumor cells in } \\
\text { FFPE block }\end{array}$ & $\begin{array}{c}\text { BRAF/NRAS } \\
\text { mutation testing } \\
\text { autologous } \\
\text { tumor cell-line }\end{array}$ & $\begin{array}{l}\text { Cell-line } \\
\text { passage }\end{array}$ & Date of birth & Gender & $\begin{array}{c}\text { Date of primitive } \\
\text { tumor exision }\end{array}$ & Breslow & $\begin{array}{l}\text { Breslow } \\
>1.5 \mathrm{~mm}\end{array}$ & Ulceration & $\begin{array}{l}\text { Capsular } \\
\text { breaking }\end{array}$ & $\begin{array}{c}\text { Date of LN } \\
\text { exision }\end{array}$ & $\begin{array}{l}\text { Adjuvant } \\
\text { treatment }\end{array}$ & $\begin{array}{c}\text { Age at } L N \\
\text { exision }\end{array}$ & \begin{tabular}{|c|} 
Number of \\
invaded $L N s$
\end{tabular} & $\begin{array}{c}\text { Date of } \\
\text { progression }\end{array}$ & $\begin{array}{c}\text { Age at } \\
\text { progression }\end{array}$ & $\begin{array}{c}\text { Type of } \\
\text { progression }\end{array}$ & Date of death & Age at death & $\begin{array}{l}\text { Date of last } \\
\text { news }\end{array}$ \\
\hline 2 & 1 & III & p.061R & 65 & p.061R & ND & $30 / 06 / 1941$ & $\mathrm{M}$ & $28 / 11 / 1990$ & 0,5 & 0 & $\mathrm{NA}$ & 1 & 21/1/1/1994 & $T \mathrm{TL}+\mathrm{IL}-2$ & 53,00 & 5 & 10/107/1995 & 54,03 & metastasis & $\begin{array}{l}07 / 01 / 1996 \\
\end{array}$ & 54,52 & $\mathrm{NA}$ \\
\hline ح & 2 & III & p.061H & 85 & p.Q61H & P33 & $01 / 1 / 12 / 1952$ & M & 01/12/19994 & 7,5 & 1 & 1 & 1 & $01 / 02 / 1995$ & $\mathrm{TIL}+\mathrm{HL}-2$ & 42,00 & 3 & no & NA & $\mathrm{NA}$ & no & $\mathrm{NA}$ & $10 / 05 / 2016$ \\
\hline 3 & 3 & III & p.V600E & 90 & p.V600E & P5 & $20 / 02 / 1946$ & M & NK/NK/1994 & 3,4 & 1 & 1 & 1 & 16//02/1995 & $\mathrm{IL}-2$ & 48,00 & 1 & 22/01/1996 & 49,92 & metastasis & 02/05/1997 & 51,20 & $\mathrm{NA}$ \\
\hline 4 & 4 & III & p.V600k & 50 & p.V600K & P6 & $23 / 12 / 1939$ & M & 02/07/1994 & 0,98 & 0 & $\mathrm{NA}$ & 1 & 16/03/1995 & $\mathrm{IL}-2$ & 55,00 & 2 & $13 / 06 / 1995$ & 55,47 & $\begin{array}{l}\text { regional } \\
\end{array}$ & 29/08/1996 & 56,68 & NA \\
\hline 5 & 5 & III & wt & 85 & wt & P7 & $03 / 03 / 1939$ & $M$ & $23 / 02 / 1995$ & 2,36 & 1 & $\mathrm{NA}$ & 0 & $30 / 03 / 1995$ & $\mathrm{IL}-2$ & 56,00 & 5 & 06/106/1995 & 56,26 & metastasis & 24/06/1995 & 56,31 & $\mathrm{NA}$ \\
\hline & 6 & III & wt & 60 & wt & P6 & $11108 / 1944$ & $M$ & 13/07/1994 & 3,68 & 1 & 1 & 0 & $22206 / 1995$ & TIL + IL-2 & 50,00 & 6 & $25 / 09 / 1995$ & 51,12 & metastasis & 09/01/1996 & 51,41 & $\mathrm{NA}$ \\
\hline 6 & 7 & III & p.061R & 90 & p.061R & P4 & $23 / 02 / 1941$ & $F$ & 15/11/1993 & 1 & 0 & $\mathrm{NA}$ & 0 & $20107 / 1995$ & $\mathrm{IL}-2$ & 54,00 & 3 & 25/01/1996 & 54,92 & metastasis & 25/01/1996 & 54,92 & $\mathrm{NA}$ \\
\hline 7 & 8 & IIII & wt & 70 & wt & P15 & $24 / 03 / 1946$ & $M$ & $22 / 03 / 1995$ & 0,8 & 0 & $\mathrm{NA}$ & 0 & $05 / 10 / 1995$ & $T \mathrm{TL}+\mathrm{IL}-2$ & 49,00 & 2 & no & $\mathrm{NA}$ & $\mathrm{NA}$ & no & $\mathrm{NA}$ & $10 / 05 / 2016$ \\
\hline & 9 & III & p.V600E & 80 & p.V600E & P10 & 19/07/1945 & $M$ & 12/12/1995 & 3,4 & 1 & $\mathrm{NA}$ & 1 & 12/12/1995 & $\mathrm{IL}-2$ & 50,00 & 1 & 22202/1996 & 50,60 & regional & $05 / 01 / 1997$ & 51,47 & $\mathrm{NA}$ \\
\hline 8 & 10 & IIII & p.V600E & 75 & p.V600E & P10 & $02 / 04 / 1947$ & $M$ & $12 / 12 / 1995$ & 3,9 & 1 & 1 & 0 & $25 / 04 / 1996$ & $\mathrm{IL}-2$ & 49,00 & 2 & 10/06/1996 & 49,19 & local & $30 / 12 / 2000$ & 53,75 & $\mathrm{NA}$ \\
\hline 9 & 11 & III & p.V600E & 80 & p.V600E & P6 & $08 / 10 / 1930$ & $M$ & 15/04/1997 & 9 & 1 & $\mathrm{NA}$ & 1 & 17/10/1996 & $\mathrm{TLL}+\mathrm{HL}-2$ & 66,00 & 2 & 23/03/1997 & 66,46 & metastasis & 15/04/1997 & 66,52 & $\mathrm{NA}$ \\
\hline & 12 & III & p.V600E & 60 & p.V600E & P4 & $07 / 1 / 1 / 1945$ & $M$ & $15 / 05 / 1996$ & 2 & 1 & 0 & 0 & $23107 / 1997$ & $\mathrm{TLL}+\mathrm{IL}-2$ & 51,00 & 1 & no & $\mathrm{NA}$ & $\mathrm{NA}$ & no & $\mathrm{NA}$ & $\begin{array}{l}0 / 05 / 2016 \\
\end{array}$ \\
\hline & 13 & III & wt & 60 & wt & P14 & $29 / 04 / 1937$ & $F$ & $19903 / 1996$ & 1,04 & 0 & $\mathrm{NA}$ & 1 & $111 / 09 / 1997$ & $\mathrm{TIL}+\mathrm{IL}-2$ & 60,00 & 2 & no & $\mathrm{NA}$ & $\mathrm{NA}$ & no & $\mathrm{NA}$ & $10 / 05 / 2016$ \\
\hline 1 & 14 & IIII & p.V600E & 50 & p.V600E & P7 & $22 / 03 / 1978$ & $\mathrm{~F}$ & $03 / 03 / 1997$ & 1,44 & 0 & 1 & 1 & 177/10/1997 & $\mathrm{IL}-2$ & 19,00 & 1 & no & $\mathrm{NA}$ & NA & no & $\mathrm{NA}$ & $10 / 05 / 2016$ \\
\hline 1 & 15 & III & p.V600R & $>90$ & p.V600R & P6 & $24 / 04 / 1925$ & M & 14/01/1997 & 3,9 & 1 & 1 & 0 & 13/11/19997 & $\mathrm{TLL}+\mathrm{HL}-2$ & 72,00 & 3 & no & $\mathrm{NA}$ & $\mathrm{NA}$ & 27/06/2000 & 75,18 & $\mathrm{NA}$ \\
\hline & 16 & III & p.V600E & 80 & p.V600E & P8 & $01 / 11 / 1 / 1963$ & $M$ & NK/01/1996 & 3,2 & 1 & $\mathrm{NA}$ & 1 & $19 / 02 / 1998$ & $\mathrm{TLL}+\mathrm{IL}-2$ & 34,00 & 1 & 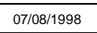 & 34,77 & metastasis & 17/06/1999 & 35,62 & $\mathrm{NA}$ \\
\hline 1. & 17 & IIII & p.V600E & 80 & p.V600E & $\mathrm{P} 12$ & $07 / 06 / 1974$ & $M$ & 17/04/1998 & 1,2 & 0 & NA & 1 & $177 / 04 / 1998$ & $\mathrm{IL}-2$ & 23,00 & 1 & 13/10/1998 & 24,35 & metastasis & 15/12/1998 & 24,52 & $\mathrm{NA}$ \\
\hline 1 & 18 & III & $p .061 \mathrm{~L}$ & 60 & p.061L & P12 & $03 / 04 / 1940$ & $M$ & $25 / 18 / 1997$ & 1,65 & 1 & 1 & 1 & $30 / 04 / 1998$ & $\mathrm{TLL}+\mathrm{HL}-2$ & 58,00 & 7 & 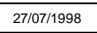 & 58,31 & Iocale & $06 / 10 / 1998$ & 58,51 & $\mathrm{NA}$ \\
\hline & 19 & III & wt & 45 & wt & P7 & $09 / 1 / 1956$ & $M$ & $20 / 01 / 1998$ & 1,35 & 0 & 1 & 0 & 23107/1998 & $\mathrm{IL}-2$ & 41,00 & 1 & no & $\mathrm{NA}$ & $\mathrm{NA}$ & no & $\mathrm{NA}$ & $10 / 05 / 2016$ \\
\hline 1 & 20 & IIII & p.V600E & 65 & p.V600E & P5 & $14 / 02 / 1949$ & $F$ & $31 / 07 / 1997$ & 6 & 1 & 1 & 1 & 03/109/1998 & $\mathrm{IL}-2$ & 49,00 & 2 & $21 / 01 / 2000$ & 50,93 & local & $07 / 01 / 2002$ & 52,90 & $\mathrm{NA}$ \\
\hline & 21 & IIII & p.V600E & 80 & p.V600E & P9 & $13 / 08 / 1952$ & $\mathrm{~F}$ & $29 / 106 / 1998$ & 8 & 1 & 0 & 1 & $16609 / 1998$ & TIL + IL-2 & 46,00 & 2 & $11105 / 1999$ & 46,74 & metastasis & $20 / 01 / 2000$ & 47,44 & $\mathrm{NA}$ \\
\hline & 22 & III & p. $061 R$ & 80 & p.061R & P13 & $03 / 03 / 1931$ & M & 12/07/2001 & 1,9 & 1 & NA & 0 & $30 / 01 / 2003$ & TLL + IL-2 & 71,00 & 1 & 24/06/2005 & 74,31 & regional & 20/03/2006 & 75,05 & $\mathrm{NA}$ \\
\hline & 23 & IIII & p.V600E & 50 & p.V600E & P40 & $14 / 11 / 1954$ & $M$ & $01 / 03 / 2003$ & 0,88 & 0 & 0 & 1 & $19 / 06 / 2003$ & $\mathrm{TLL}+\mathrm{HL}-2$ & 48,00 & 1 & $23107 / 2004$ & 49,69 & metastasis & $30 / 12 / 2004$ & 50,13 & $\mathrm{NA}$ \\
\hline & 24 & III & wt & $>90$ & wt & P5 & $12 / 06 / 1944$ & $\mathrm{~F}$ & 17705/2004 & 2,45 & 1 & 1 & 0 & 15/05/2004 & $\mathrm{TLL}+\mathrm{IL}-2$ & 59,00 & 1 & $\begin{array}{l}2107 / 2004 \\
\end{array}$ & 60,11 & regional & $09 / 04 / 2005$ & 60,82 & $\mathrm{NA}$ \\
\hline & 25 & IIII & p. $061 \mathrm{~K}$ & 60 & p.061K & P6 & $24 / 05 / 1959$ & $\mathrm{~F}$ & 15/07/1996 & 1 & 0 & 0 & 1 & $05 / 08 / 2004$ & TLL + IL-2 & 45,00 & 1 & no & NA & $\mathrm{NA}$ & no & NA & $10 / 05 / 2016$ \\
\hline & 26 & IIII & p.V600E & 50 & p.V600E & P7 & $07 / 03 / 1933$ & $\mathrm{~F}$ & $04 / 11 / 2003$ & 0,331 & 0 & 0 & 0 & $22 / 11 / 2004$ & $\mathrm{TLL}+\mathrm{IL}-2$ & 71,00 & 1 & 25/01/2006 & 72,89 & regional & 04/03/2006 & 72,99 & NA \\
\hline 29 & 27 & III & p.V600E & 85 & p.V600E & P9 & $23 / 09 / 1932$ & $F$ & $22 / 09 / 1989$ & 1,2 & 0 & $\mathrm{NA}$ & 1 & $18100 / 2005$ & $\mathrm{TLL}+\mathrm{IL}-2$ & 72,00 & 1 & 18/11/2005 & 73,15 & Iocal & no & $\mathrm{NA}$ & $\begin{array}{l}10 / 05 / 2016 \\
\end{array}$ \\
\hline 21 & 28 & III & p.061R & 60 & p.061R & P11 & $22 / 02 / 1942$ & $F$ & $04 / 12 / 2001$ & 1,04 & 0 & 0 & 0 & $03 / 106 / 2005$ & $\mathrm{TLL}+\mathrm{HL}-2$ & 63,00 & 1 & no & $\mathrm{NA}$ & $\mathrm{NA}$ & $07 / 07 / 2009$ & 67,37 & $\mathrm{NA}$ \\
\hline & 29 & III & p.061R & 80 & p.061R & P7 & $31 / 08 / 1952$ & $M$ & 23/106/2005 & 6 & 1 & 1 & 0 & $2309 / 2005$ & IFN-alpha & 53,00 & 2 & $23 / 04 / 2008$ & 55,64 & metastasis & $06 / 04 / 2009$ & 56,60 & $\mathrm{NA}$ \\
\hline & 30 & III & wt & 90 & wt & P4 & $27 / 08 / 1946$ & M & $03 / 06 / 2005$ & $>3$ & 1 & 1 & 0 & 07/10/2005 & $\mathrm{TLL}+\mathrm{IL}-2$ & 59,00 & 1 & 07/04/2006 & 59,61 & metastasis & 10/10/2006 & 60,12 & NA \\
\hline 23 & 31 & III & p.V600E & 95 & p.V600E & P9 & $02 / 10 / 1960$ & $M$ & $29 / 09 / 1998$ & 1,2 & 0 & 0 & 0 & $21 / 11 / 2005$ & $\mathrm{TLL}+\mathrm{HL}-2$ & 45,00 & 1 & no & $\mathrm{NA}$ & $\mathrm{NA}$ & no & $\mathrm{NA}$ & $\begin{array}{l}10 / 05 / 2016 \\
\end{array}$ \\
\hline & 32 & IIII & wt & 90 & wt & P8 & $10 / 10 / 1950$ & $M$ & $05 / 07 / 2005$ & 0,8 & 0 & 0 & 1 & 10/03/2006 & $\mathrm{TLL}+\mathrm{IL}-2$ & 55,00 & 1 & $23 / 06 / 2006$ & 55,70 & $\begin{array}{l}\text { regional } \\
\end{array}$ & 03/103/2007 & 56,39 & NA \\
\hline & 33 & IIII & p. $061 \mathrm{R}$ & 90 & p.061R & P10 & $02 / 03 / 1942$ & $F$ & NK/12/1997 & 1,8 & 1 & $\mathrm{NA}$ & 1 & 10/03/2006 & None & 64,00 & 2 & no & $\mathrm{NA}$ & $\mathrm{NA}$ & no & $\mathrm{NA}$ & $10 / 05 / 2016$ \\
\hline 25 & 34 & III & p.061L & 75 & p. $061 \mathrm{~L}$ & P6 & $30 / 03 / 1955$ & M & 22/08/2005 & 2 & 1 & NA & 1 & $05 / 05 / 2006$ & None & 51,00 & 1 & 24/11/2006 & 51,66 & reg & $16 / 07 / 2008$ & 53,30 & NA \\
\hline 2 & 35 & IIII & wt & $<5$ & wt & P5 & $05 / 06 / 1950$ & $M$ & $27 / 06 / 2005$ & 4 & 1 & 0 & 1 & $21 / 06 / 2006$ & IFN-alpha & 56,00 & 6 & 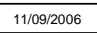 & 56,27 & metastasis & $20 / 08 / 2007$ & 57,21 & $\mathrm{NA}$ \\
\hline & 36 & III & p.V600E & 35 & p.V600E & P10 & $111 / 02 / 1943$ & $M$ & 30/12/2004 & 1,45 & 0 & 0 & 1 & 177/11/2006 & IFN-alpha & 63,00 & 3 & $04 / 05 / 2007$ & 64,22 & Iocal & $05 / 10 / 2008$ & 65,65 & $\mathrm{NA}$ \\
\hline 2 & 37 & IIII & p.V600E & 90 & p.V600E & P7 & $14 / 12 / 1970$ & $\mathrm{~F}$ & $055 / 12 / 2005$ & 2 & 1 & 0 & 1 & 15/12/2006 & None & 36,00 & 1 & $29 / 01 / 2007$ & 36,13 & metastasis & $28 / 04 / 2007$ & 36,37 & $\mathrm{NA}$ \\
\hline 28 & 38 & III & p.V600E & 85 & p.V600E & P7 & $13 / 01 / 1954$ & M & 24/03/1995 & 4 & 1 & NA & 1 & $26 / 101 / 2007$ & IFN-alpha & 53,00 & 4 & 11/09/2007 & 53,66 & regional & 04/07/2008 & 54,47 & NA \\
\hline & 39 & III & p.V600E & 60 & p.V600E & P7 & $07 / 12 / 1957$ & $F$ & $28 / 09 / 2006$ & 4,8 & 1 & 1 & 1 & 30/03/2007 & IFN-alpha & 49,00 & 4 & 28/12/2007 & 50,06 & metastasis & 03/06/2008 & 50,49 & $\mathrm{NA}$ \\
\hline & 40 & III & p.061K & 80 & p.061K & P6 & $13 / 01 / 1948$ & $\mathrm{~F}$ & 30/04/2007 & 9 & 1 & $\mathrm{NA}$ & 1 & 19/07/2007 & IFN-alpha & 59,00 & 2 & $\begin{array}{l}18 / 03 / 2010 \\
\end{array}$ & 62,18 & locale & 25/05/2011 & 63,36 & $\mathrm{NA}$ \\
\hline 30 & 41 & IIII & p.V600E & 80 & p.V600E & P7 & $12 / 12 / 1970$ & $M$ & 17/03/2006 & 0,6 & 0 & $\mathrm{NA}$ & 1 & $30 / 08 / 20007$ & IFN-alpha & 36,00 & 3 & 19/11/2007 & 36,94 & regional & 27/03/2008 & 37,29 & $\mathrm{NA}$ \\
\hline & 42 & III & p.V600K & 95 & p.V600K & P7 & $22 / 08 / 1944$ & M & 09/10/2006 & 2,4 & 1 & 0 & 0 & 13/12/2007 & IFN-alpha & 63,00 & 2 & 23/09/2008 & 64,09 & regional & no & NA & $10 / 05 / 2016$ \\
\hline & 43 & IIII & p.V600E & 50 & p.V600E & P7 & $16 / 10 / 1951$ & M & 19/02/2007 & 0,36 & 0 & NA & 1 & 13/12/2007 & IFN-alpha & 56,00 & $>1$ & 07/04/2008 & 56,48 & metastasis & 20/07/2008 & 56,76 & NA \\
\hline 32 & 44 & IIII & p.061K & 85 & p.061K & P6 & $04 / 08 / 1959$ & $M$ & $23 / 10 / 2007$ & 5,51 & 1 & 0 & 0 & $08 / 02 / 2008$ & None & 48,00 & 1 & 11108/2008 & 49,02 & locale & 10/06/2011 & 51,85 & $\mathrm{NA}$ \\
\hline & 45 & III & p.V600E & 85 & p.V6000E & P8 & 10/03/1959 & $M$ & $\begin{array}{l}1 / 02 / 2007 \\
\end{array}$ & 2,7 & 1 & 0 & 0 & 15/02/2008 & TIL + IL-2 & 48,00 & 1 & 19/06/2008 & 49,28 & regional & $03 / 08 / 2008$ & 49,40 & NA \\
\hline & 46 & IIII & p.061R & 10 & p.061R & P7 & $25 / 09 / 1947$ & M & 26/106/2007 & 2,9 & 1 & 0 & 1 & 25/02/2008 & IFN-alpha & 60,00 & 3 & 31/12/2008 & 61,27 & metastasis & 11//01/2010 & 62,30 & NA \\
\hline 3 & 47 & III & wt & 85 & wt & P4 & $25 / 05 / 1980$ & $M$ & $02 / 03 / 2006$ & 1,3 & 0 & 0 & 1 & 12/03/2008 & IFN-alpha & 27,00 & 8 & $29 / 04 / 2008$ & 27,93 & $\begin{array}{l}\text { regional } \\
\end{array}$ & no & NA & $10 / 05 / 2016$ \\
\hline 35 & 48 & III & p.061K & 40 & p.061K & P6 & $31 / 01 / 1948$ & $M$ & $04 / 08 / 2003$ & 1,39 & 0 & $\mathrm{NA}$ & 1 & 19//05/2008 & None & 60,00 & 2 & 21/08/2008 & 60,56 & reg + meta & $06 / 02 / 2009$ & 61,02 & $\mathrm{NA}$ \\
\hline & 49 & III & p.V600E & 60 & p.V600E & P8 & $20 / 11 / 1962$ & $\mathrm{~F}$ & 02/05/2008 & 4,83 & 1 & 1 & 0 & 11107/2008 & IFN-alpha & 45,00 & 2 & 177/07/2009 & 46,66 & Iocal & 16/07/2010 & 47,65 & NA \\
\hline & 50 & IIII & p. $061 R$ & 90 & p.061R & P5 & $21 / 06 / 1954$ & $M$ & $05 / 06 / 2007$ & 0,34 & 0 & 0 & 1 & $02 / 12 / 2009$ & $\mathrm{TLL}+\mathrm{IL}-2$ & 55,00 & 1 & $26 / 108 / 2010$ & 56,18 & metastasis & $03 / 11 / 2010$ & 56,37 & $\mathrm{NA}$ \\
\hline
\end{tabular}

40 Table 2 : Detailed clinico-biological characteristics of the 50 melanoma patients 


\begin{tabular}{|c|c|c|c|c|c|c|c|c|c|c|c|c|c|c|c|c|c|c|c|c|c|}
\hline \multirow{2}{*}{\multicolumn{2}{|c|}{$\begin{array}{c}\begin{array}{c}\text { Patients } \\
\text { code }\end{array} \\
\end{array}$}} & \multicolumn{2}{|c|}{ CMH I } & \multicolumn{2}{|c|}{ CMH II } & \multicolumn{2}{|c|}{ MCSP } & \multicolumn{2}{|c|}{ gp100 } & \multicolumn{2}{|c|}{ NYESO1 } & \multicolumn{2}{|c|}{ Melan-A } & \multicolumn{2}{|c|}{ tyrosinase } & \multicolumn{2}{|c|}{ MAGEs } & \multicolumn{2}{|c|}{ PD-L1 } & \multicolumn{2}{|c|}{ IDO1 } \\
\hline & & untreated & + IFN & untreated & + IFN & untreated & + IFN & untreated & + IFN & untreated & + IFN & untreated & + IFN & untreated & + IFN & untreated & + IFN & untreated & + IFN & untreated & $+\mathrm{IFN}$ \\
\hline & 1 & $91,26 \%$ & $86,05 \%$ & $68,65 \%$ & $85,83 \%$ & $88,98 \%$ & $87,83 \%$ & $93,63 \%$ & $85,81 \%$ & $61,66 \%$ & $0,33 \%$ & $86,12 \%$ & $78,36 \%$ & $76,57 \%$ & $58,02 \%$ & $39,20 \%$ & $0,38 \%$ & $71,46 \%$ & $79,42 \%$ & $53,72 \%$ & $81,94 \%$ \\
\hline & 2 & $83,11 \%$ & $96,71 \%$ & $19,88 \%$ & $88,15 \%$ & $62,90 \%$ & $78,36 \%$ & $89,12 \%$ & $89,36 \%$ & $77,16 \%$ & $72,92 \%$ & $78,02 \%$ & $75,84 \%$ & $77,07 \%$ & $79,88 \%$ & $62,17 \%$ & $54,58 \%$ & $0,00 \%$ & $84,87 \%$ & $0,00 \%$ & $0,00 \%$ \\
\hline 2 & 3 & $93,74 \%$ & $88,99 \%$ & $92,21 \%$ & $92,65 \%$ & $96,87 \%$ & $90,59 \%$ & $80,20 \%$ & $62,77 \%$ & $38,82 \%$ & $1,98 \%$ & $89,76 \%$ & $58,20 \%$ & $88,18 \%$ & $52,72 \%$ & $78,17 \%$ & $0,00 \%$ & $0,00 \%$ & $77,71 \%$ & $80,22 \%$ & $67,38 \%$ \\
\hline 3 & 4 & $79,96 \%$ & $77,55 \%$ & $16,40 \%$ & $19,85 \%$ & $89,59 \%$ & $87,45 \%$ & $80,39 \%$ & $83,34 \%$ & $75,35 \%$ & $65,79 \%$ & $73,55 \%$ & $81,11 \%$ & $80,68 \%$ & $81,41 \%$ & $18,39 \%$ & $31,02 \%$ & $82,16 \%$ & $78,83 \%$ & $74,01 \%$ & $64,31 \%$ \\
\hline & 5 & $81,57 \%$ & $86,50 \%$ & $59,29 \%$ & $73,84 \%$ & $96,57 \%$ & $92,50 \%$ & $74,23 \%$ & $75,06 \%$ & $62,81 \%$ & $55,69 \%$ & $86,16 \%$ & $75,48 \%$ & $51,45 \%$ & $36,52 \%$ & $0,40 \%$ & $1,01 \%$ & $86,72 \%$ & $80,59 \%$ & $53,45 \%$ & $51,43 \%$ \\
\hline & 6 & $100,00 \%$ & $100,00 \%$ & $0,00 \%$ & $91,10 \%$ & $95,48 \%$ & $95,90 \%$ & $0,00 \%$ & $100,00 \%$ & $80,38 \%$ & $57,39 \%$ & $94,77 \%$ & $96,13 \%$ & $0,00 \%$ & $63,38 \%$ & $42,65 \%$ & $49,14 \%$ & $100,00 \%$ & $100,00 \%$ & $0,00 \%$ & $0,00 \%$ \\
\hline כ & 7 & $92,78 \%$ & $83,97 \%$ & $85,18 \%$ & $79,79 \%$ & $0,00 \%$ & $0,00 \%$ & $61,16 \%$ & $71,34 \%$ & $0,00 \%$ & $0,00 \%$ & $57,54 \%$ & $51,62 \%$ & $66,55 \%$ & $48,21 \%$ & $28,79 \%$ & $14,22 \%$ & $0,00 \%$ & $72,64 \%$ & $0,00 \%$ & $16,27 \%$ \\
\hline 6 & 8 & $66,39 \%$ & $37,34 \%$ & $88,88 \%$ & $84,86 \%$ & $94,12 \%$ & $95,46 \%$ & $54,97 \%$ & $78,65 \%$ & $33,61 \%$ & $4,71 \%$ & $81,61 \%$ & $84,86 \%$ & $43,95 \%$ & $31,08 \%$ & $25,70 \%$ & $11,99 \%$ & $2,39 \%$ & $2,44 \%$ & $40,58 \%$ & $24,72 \%$ \\
\hline 7 & 9 & $82,47 \%$ & $76,40 \%$ & $70,49 \%$ & $63,54 \%$ & $1,18 \%$ & $0,57 \%$ & $0,57 \%$ & $0,35 \%$ & $0,29 \%$ & $0,28 \%$ & $0,43 \%$ & $0,30 \%$ & $0,35 \%$ & $0,11 \%$ & $0,40 \%$ & $0,26 \%$ & $76,72 \%$ & $82,74 \%$ & $1,22 \%$ & $3,42 \%$ \\
\hline & 10 & $78,11 \%$ & $77,04 \%$ & $39,26 \%$ & $80,43 \%$ & $94,61 \%$ & $92,26 \%$ & $53,44 \%$ & $35,76 \%$ & $72,25 \%$ & $0,24 \%$ & $66,43 \%$ & $49,03 \%$ & $51,04 \%$ & $11,09 \%$ & $36,51 \%$ & $0,90 \%$ & $0,14 \%$ & $71,95 \%$ & $0,84 \%$ & $64,88 \%$ \\
\hline 8 & 11 & $85,54 \%$ & $83,02 \%$ & $59,99 \%$ & $70,43 \%$ & $59,89 \%$ & $53,37 \%$ & $0,15 \%$ & $0,03 \%$ & $0,81 \%$ & $0,20 \%$ & $0,20 \%$ & $0,45 \%$ & $0,27 \%$ & $0,54 \%$ & $1,03 \%$ & $1,06 \%$ & $0,14 \%$ & $57,10 \%$ & $7,22 \%$ & $56,37 \%$ \\
\hline 9 & 12 & $95,93 \%$ & $93,62 \%$ & $78,56 \%$ & $94,46 \%$ & $97,35 \%$ & $93,24 \%$ & $87,75 \%$ & $80,99 \%$ & $70,51 \%$ & $24,28 \%$ & $79,65 \%$ & $55,21 \%$ & $77,08 \%$ & $68,60 \%$ & $53,81 \%$ & $27,76 \%$ & $0,00 \%$ & $29,97 \%$ & $41,70 \%$ & $70,14 \%$ \\
\hline 1 & 13 & $76,99 \%$ & $71,73 \%$ & $0,99 \%$ & $61,94 \%$ & $86,65 \%$ & $86,14 \%$ & $60,05 \%$ & $66,21 \%$ & $55,75 \%$ & $44,88 \%$ & $65,42 \%$ & $69,56 \%$ & $74,80 \%$ & $75,09 \%$ & $53,25 \%$ & $17,12 \%$ & $18,26 \%$ & $62,41 \%$ & $52,26 \%$ & $44,35 \%$ \\
\hline & 14 & $72,22 \%$ & $61,31 \%$ & $61,93 \%$ & $75,97 \%$ & $81,88 \%$ & $71,41 \%$ & $3,52 \%$ & $1,79 \%$ & $0,31 \%$ & $0,69 \%$ & $2,42 \%$ & $0,48 \%$ & $0,19 \%$ & $1,48 \%$ & $0,20 \%$ & $0,37 \%$ & $80,57 \%$ & $78,98 \%$ & $56,30 \%$ & $7,56 \%$ \\
\hline & 15 & $92,68 \%$ & $85,90 \%$ & $83,57 \%$ & $72,04 \%$ & $50,04 \%$ & $36,15 \%$ & $58,45 \%$ & $62,23 \%$ & $1,24 \%$ & $2,21 \%$ & $60,57 \%$ & $58,81 \%$ & $1,89 \%$ & $60,20 \%$ & $1,60 \%$ & $1,88 \%$ & $66,86 \%$ & $66,68 \%$ & $15,09 \%$ & $64,88 \%$ \\
\hline 12 & 216 & $100,00 \%$ & $100,00 \%$ & $45,37 \%$ & $73,21 \%$ & $95,37 \%$ & $95,39 \%$ & $100,00 \%$ & $100,00 \%$ & $97,93 \%$ & $69,07 \%$ & $99,75 \%$ & $97,62 \%$ & $97,15 \%$ & $100,00 \%$ & $100,00 \%$ & $52,45 \%$ & $100,00 \%$ & $46,36 \%$ & $0,00 \%$ & $49,04 \%$ \\
\hline 13 & 317 & $96,48 \%$ & $92,16 \%$ & $76,92 \%$ & $94,29 \%$ & $98,93 \%$ & $98,28 \%$ & $47,60 \%$ & $72,19 \%$ & $0,23 \%$ & $0,23 \%$ & $59,95 \%$ & $65,52 \%$ & $0,17 \%$ & $64,95 \%$ & $0,20 \%$ & $70,58 \%$ & $0,34 \%$ & $88,14 \%$ & $77,75 \%$ & $39,82 \%$ \\
\hline & 18 & $84,10 \%$ & $67,12 \%$ & $69,85 \%$ & $76,55 \%$ & $90,46 \%$ & $86,80 \%$ & $83,82 \%$ & $58,42 \%$ & $91,97 \%$ & $51,92 \%$ & $91,20 \%$ & $69,97 \%$ & $78,70 \%$ & $47,96 \%$ & $28,39 \%$ & $27,28 \%$ & $39,66 \%$ & $83,26 \%$ & $0,62 \%$ & $3,49 \%$ \\
\hline & 19 & $93,64 \%$ & $93,45 \%$ & $91,50 \%$ & $86,32 \%$ & $94,54 \%$ & $92,31 \%$ & $38,51 \%$ & $42,99 \%$ & $69,63 \%$ & $60,88 \%$ & $71,26 \%$ & $59,90 \%$ & $83,08 \%$ & $87,01 \%$ & $94,06 \%$ & $91,43 \%$ & $15,88 \%$ & $4,63 \%$ & $37,75 \%$ & $55,75 \%$ \\
\hline 15 & 520 & $89,09 \%$ & $81,74 \%$ & $23,72 \%$ & $66,01 \%$ & $92,54 \%$ & $91,42 \%$ & $62,07 \%$ & $63,06 \%$ & $50,14 \%$ & $46,13 \%$ & $70,60 \%$ & $55,75 \%$ & $74,82 \%$ & $62,25 \%$ & $60,95 \%$ & $37,28 \%$ & $0,08 \%$ & $57,71 \%$ & $37,74 \%$ & $43,83 \%$ \\
\hline 16 & $6^{21}$ & $89,52 \%$ & $88,26 \%$ & $70,76 \%$ & $68,07 \%$ & $86,35 \%$ & $84,92 \%$ & $82,51 \%$ & $70,72 \%$ & $87,11 \%$ & $26,03 \%$ & $87,87 \%$ & $53,02 \%$ & $89,11 \%$ & $70,21 \%$ & $80,48 \%$ & $8,34 \%$ & $0,00 \%$ & $77,66 \%$ & $77,68 \%$ & $25,11 \%$ \\
\hline & 22 & $98,50 \%$ & $95,53 \%$ & $99,20 \%$ & $97,84 \%$ & $98,43 \%$ & $97,36 \%$ & $64,49 \%$ & $86,74 \%$ & $84,90 \%$ & $84,33 \%$ & $75,08 \%$ & $82,08 \%$ & $84,33 \%$ & $77,52 \%$ & $51,11 \%$ & $73,43 \%$ & $0,00 \%$ & $80,59 \%$ & $89,74 \%$ & $82,58 \%$ \\
\hline 1 & 23 & $85,95 \%$ & $96,18 \%$ & $60,46 \%$ & $85,06 \%$ & $97,15 \%$ & $97,38 \%$ & $90,43 \%$ & $89,81 \%$ & $51,81 \%$ & $41,50 \%$ & $91,82 \%$ & $89,35 \%$ & $81,25 \%$ & $82,73 \%$ & $43,30 \%$ & $55,05 \%$ & $49,22 \%$ & $75,30 \%$ & $89,38 \%$ & $80,33 \%$ \\
\hline 18 & 824 & $83,43 \%$ & $84,58 \%$ & $84,20 \%$ & $85,14 \%$ & $1,60 \%$ & $2,82 \%$ & $0,20 \%$ & $0,19 \%$ & $0,13 \%$ & $0,04 \%$ & $0,19 \%$ & $0,05 \%$ & $0,49 \%$ & $0,22 \%$ & $0,23 \%$ & $0,07 \%$ & $0,06 \%$ & $76,71 \%$ & $80,25 \%$ & $84,30 \%$ \\
\hline 15 & 925 & $94,27 \%$ & $95,88 \%$ & $96,36 \%$ & $97,84 \%$ & $79,16 \%$ & $83,78 \%$ & $93,39 \%$ & $93,68 \%$ & $54,59 \%$ & $47,99 \%$ & $90,48 \%$ & $90,58 \%$ & $90,08 \%$ & $84,05 \%$ & $54,15 \%$ & $47,94 \%$ & $0,76 \%$ & $86,21 \%$ & $91,95 \%$ & $94,18 \%$ \\
\hline & 26 & $0,00 \%$ & $100,00 \%$ & $1,59 \%$ & $84,84 \%$ & $83,83 \%$ & $80,16 \%$ & $0,00 \%$ & $0,00 \%$ & $92,91 \%$ & $86,89 \%$ & $85,21 \%$ & $58,13 \%$ & $100,00 \%$ & $100,00 \%$ & $60,24 \%$ & $25,16 \%$ & $0,00 \%$ & $0,00 \%$ & $100,00 \%$ & $100,00 \%$ \\
\hline & 27 & $96,52 \%$ & $90,15 \%$ & $93,90 \%$ & $88,89 \%$ & $98,81 \%$ & $97,49 \%$ & $66,58 \%$ & $58,02 \%$ & $88,01 \%$ & $82,79 \%$ & $90,03 \%$ & $83,62 \%$ & $78,68 \%$ & $71,13 \%$ & $83,67 \%$ & $76,32 \%$ & $0,00 \%$ & $91,45 \%$ & $0,00 \%$ & $0,00 \%$ \\
\hline $2 \pi$ & 128 & $92,85 \%$ & $95,14 \%$ & $73,73 \%$ & $89,43 \%$ & $91,92 \%$ & $89,85 \%$ & $17,89 \%$ & $34,46 \%$ & $78,57 \%$ & $69,10 \%$ & $74,53 \%$ & $69,47 \%$ & $7,07 \%$ & $13,47 \%$ & $30,06 \%$ & $31,72 \%$ & $87,76 \%$ & $92,85 \%$ & $76,00 \%$ & $75,04 \%$ \\
\hline $2 \sqrt{2}$ & 229 & $86,01 \%$ & $87,31 \%$ & $54,80 \%$ & $54,93 \%$ & $63,03 \%$ & $46,43 \%$ & $80,54 \%$ & $79,88 \%$ & $52,12 \%$ & $52,51 \%$ & $73,09 \%$ & $70,13 \%$ & $48,82 \%$ & $34,15 \%$ & $38,38 \%$ & $21,17 \%$ & $0,84 \%$ & $1,12 \%$ & $11,32 \%$ & $24,83 \%$ \\
\hline & 30 & $96,04 \%$ & $69,27 \%$ & $88,11 \%$ & $79,83 \%$ & $59,52 \%$ & $42,58 \%$ & $0,00 \%$ & $0,00 \%$ & $6,35 \%$ & $0,26 \%$ & $0,00 \%$ & $0,00 \%$ & $0,22 \%$ & $0,07 \%$ & $0,25 \%$ & $0,26 \%$ & $0,05 \%$ & $83,39 \%$ & $22,34 \%$ & $58,27 \%$ \\
\hline & 31 & $72,15 \%$ & $64,23 \%$ & $73,70 \%$ & $70,44 \%$ & $82,13 \%$ & $69,32 \%$ & $77,96 \%$ & $74,46 \%$ & $72,04 \%$ & $70,33 \%$ & $77,29 \%$ & $66,00 \%$ & $65,99 \%$ & $67,84 \%$ & $78,29 \%$ & $61,39 \%$ & $0,65 \%$ & $0,89 \%$ & $0,60 \%$ & $28,70 \%$ \\
\hline 24 & 432 & $71,17 \%$ & $74,60 \%$ & $56,74 \%$ & $47,23 \%$ & $54,77 \%$ & $57,33 \%$ & $75,40 \%$ & $72,04 \%$ & $50,67 \%$ & $48,81 \%$ & $61,21 \%$ & $65,08 \%$ & $56,58 \%$ & $57,42 \%$ & $0,21 \%$ & $53,31 \%$ & $0,50 \%$ & $52,77 \%$ & $1,39 \%$ & $43,08 \%$ \\
\hline 25 & 533 & $87,71 \%$ & $83,58 \%$ & $92,10 \%$ & $90,21 \%$ & $94,59 \%$ & $88,32 \%$ & $74,94 \%$ & $72,66 \%$ & $52,87 \%$ & $33,08 \%$ & $73,43 \%$ & $51,69 \%$ & $88,09 \%$ & $58,42 \%$ & $59,00 \%$ & $29,64 \%$ & $0,13 \%$ & $87,99 \%$ & $56,22 \%$ & $71,59 \%$ \\
\hline & 34 & $91,24 \%$ & $83,25 \%$ & $66,77 \%$ & $92,38 \%$ & $94,69 \%$ & $91,37 \%$ & $90,71 \%$ & $88,16 \%$ & $52,91 \%$ & $36,19 \%$ & $89,66 \%$ & $69,69 \%$ & $86,05 \%$ & $52,83 \%$ & $100,00 \%$ & $100,00 \%$ & $0,00 \%$ & $58,78 \%$ & $0,00 \%$ & $100,00 \%$ \\
\hline & 35 & $96,67 \%$ & $88,89 \%$ & $84,90 \%$ & $94,18 \%$ & $99,42 \%$ & $99,07 \%$ & $69,45 \%$ & $44,35 \%$ & $64,80 \%$ & $62,17 \%$ & $82,36 \%$ & $77,51 \%$ & $72,61 \%$ & $57,11 \%$ & $55,41 \%$ & $57,69 \%$ & $0,10 \%$ & $92,18 \%$ & $66,58 \%$ & $86,93 \%$ \\
\hline 27 & 736 & $75,92 \%$ & $69,91 \%$ & $66,59 \%$ & $79,77 \%$ & $94,43 \%$ & $95,90 \%$ & $71,01 \%$ & $39,98 \%$ & $19,09 \%$ & $8,93 \%$ & $72,73 \%$ & $70,61 \%$ & $83,13 \%$ & $61,75 \%$ & $48,36 \%$ & $36,21 \%$ & $0,11 \%$ & $0,15 \%$ & $26,94 \%$ & $51,19 \%$ \\
\hline 28 & 837 & $100,00 \%$ & $100,00 \%$ & $85,29 \%$ & $98,09 \%$ & $99,35 \%$ & $98,01 \%$ & $0,00 \%$ & $100,00 \%$ & $97,00 \%$ & $86,88 \%$ & $94,41 \%$ & $91,51 \%$ & $100,00 \%$ & $100,00 \%$ & $100,00 \%$ & $0,00 \%$ & $100,00 \%$ & $100,00 \%$ & $100,00 \%$ & $100,00 \%$ \\
\hline a & 38 & $93,33 \%$ & $83,90 \%$ & $70,50 \%$ & $58,99 \%$ & $95,60 \%$ & $94,78 \%$ & $80,17 \%$ & $77,95 \%$ & $40,31 \%$ & $68,62 \%$ & $71,69 \%$ & $74,36 \%$ & $74,21 \%$ & $70,80 \%$ & $47,04 \%$ & $63,92 \%$ & $69,05 \%$ & $65,95 \%$ & $1,05 \%$ & $71,48 \%$ \\
\hline & 39 & $91,87 \%$ & $80,98 \%$ & $44,58 \%$ & $75,00 \%$ & $90,65 \%$ & $88,84 \%$ & $0,33 \%$ & $0,37 \%$ & $0,22 \%$ & $0,52 \%$ & $0,21 \%$ & $0,58 \%$ & $0,19 \%$ & $0,19 \%$ & $0,33 \%$ & $0,59 \%$ & $0,38 \%$ & $90,84 \%$ & $88,20 \%$ & $78,88 \%$ \\
\hline 30 & D & $100,00 \%$ & $83,37 \%$ & $1,46 \%$ & $18,02 \%$ & $90,64 \%$ & $85,22 \%$ & $96,56 \%$ & $94,75 \%$ & $90,14 \%$ & $100,00 \%$ & $90,67 \%$ & $83,84 \%$ & $95,19 \%$ & $89,44 \%$ & $82,09 \%$ & $78,33 \%$ & $0,00 \%$ & $100,00 \%$ & $0,00 \%$ & $0,00 \%$ \\
\hline $3 \overline{1}$ & 141 & $87,55 \%$ & $63,13 \%$ & $70,68 \%$ & $52,19 \%$ & $94,49 \%$ & $93,40 \%$ & $52,41 \%$ & $54,94 \%$ & $0,35 \%$ & $0,28 \%$ & $73,77 \%$ & $64,41 \%$ & $0,28 \%$ & $0,26 \%$ & $0,39 \%$ & $0,38 \%$ & $0,09 \%$ & $75,48 \%$ & $14,24 \%$ & $37,28 \%$ \\
\hline 36 & 42 & $100,00 \%$ & $100,00 \%$ & $0,00 \%$ & $70,85 \%$ & $97,54 \%$ & $98,21 \%$ & $0,00 \%$ & $100,00 \%$ & $99,26 \%$ & $95,39 \%$ & $99,64 \%$ & $97,80 \%$ & $100,00 \%$ & $0,00 \%$ & $100,00 \%$ & $49,97 \%$ & $0,00 \%$ & $0,00 \%$ & $0,00 \%$ & $0,00 \%$ \\
\hline & 43 & $80,52 \%$ & $73,36 \%$ & $90,07 \%$ & $86,10 \%$ & $69,52 \%$ & $45,03 \%$ & $37,22 \%$ & $0,27 \%$ & $14,12 \%$ & $0,42 \%$ & $35,09 \%$ & $21,68 \%$ & $50,25 \%$ & $1,13 \%$ & $0,88 \%$ & $0,41 \%$ & $2,45 \%$ & $60,42 \%$ & $70,98 \%$ & $66,42 \%$ \\
\hline $3 \beta$ & B 44 & $90,78 \%$ & $88,30 \%$ & $87,65 \%$ & $86,36 \%$ & $95,64 \%$ & $89,10 \%$ & $69,73 \%$ & $63,29 \%$ & $47,98 \%$ & $39,66 \%$ & $74,42 \%$ & $51,70 \%$ & $91,09 \%$ & $74,22 \%$ & $79,22 \%$ & $53,59 \%$ & $0,40 \%$ & $80,62 \%$ & $93,53 \%$ & $87,60 \%$ \\
\hline 34 & 445 & $81,90 \%$ & $76,21 \%$ & $23,68 \%$ & $54,15 \%$ & $90,48 \%$ & $84,34 \%$ & $7,12 \%$ & $60,06 \%$ & $9,11 \%$ & $2,04 \%$ & $29,08 \%$ & $51,46 \%$ & $8,89 \%$ & $5,10 \%$ & $1,98 \%$ & $2,17 \%$ & $0,12 \%$ & $68,14 \%$ & $0,28 \%$ & $65,56 \%$ \\
\hline 35 & 546 & $100,00 \%$ & $100,00 \%$ & $58,65 \%$ & $98,88 \%$ & $99,78 \%$ & $97,96 \%$ & $0,00 \%$ & $53,09 \%$ & $0,68 \%$ & $0,00 \%$ & $100,00 \%$ & $0,00 \%$ & $84,47 \%$ & $58,51 \%$ & $100,00 \%$ & $0,00 \%$ & $100,00 \%$ & $100,00 \%$ & $0,00 \%$ & $100,00 \%$ \\
\hline & 47 & $91,59 \%$ & $91,44 \%$ & $31,44 \%$ & $25,62 \%$ & $93,51 \%$ & $93,44 \%$ & $48,20 \%$ & $50,97 \%$ & $24,48 \%$ & $18,01 \%$ & $85,77 \%$ & $85,47 \%$ & $23,36 \%$ & $28,58 \%$ & $41,55 \%$ & $11,49 \%$ & $82,99 \%$ & $74,84 \%$ & $36,23 \%$ & $23,45 \%$ \\
\hline 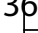 & O 48 & $76,48 \%$ & $55,87 \%$ & $0,71 \%$ & $1,28 \%$ & $0,46 \%$ & $0,18 \%$ & $70,58 \%$ & $78,56 \%$ & $23,22 \%$ & $42,88 \%$ & $63,26 \%$ & $61,89 \%$ & $22,78 \%$ & $10,58 \%$ & $18,58 \%$ & $26,25 \%$ & $0,06 \%$ & $42,56 \%$ & $0,20 \%$ & $36,65 \%$ \\
\hline $3 \bar{\nabla}$ & 749 & $47,43 \%$ & $39,34 \%$ & $48,12 \%$ & $46,07 \%$ & $38,78 \%$ & $34,46 \%$ & $52,07 \%$ & $49,00 \%$ & $0,17 \%$ & $0,27 \%$ & $44,57 \%$ & $41,36 \%$ & $1,76 \%$ & $2,13 \%$ & $0,31 \%$ & $0,25 \%$ & $0,15 \%$ & $39,81 \%$ & $0,26 \%$ & $0,35 \%$ \\
\hline 36 & 850 & $90,95 \%$ & $81,93 \%$ & $31,19 \%$ & $67,12 \%$ & $63,16 \%$ & $57,52 \%$ & $79,85 \%$ & $81,49 \%$ & $81,01 \%$ & $10,50 \%$ & $88,97 \%$ & $74,74 \%$ & $81,95 \%$ & $85,84 \%$ & $75,08 \%$ & $68,61 \%$ & $0,03 \%$ & $79,85 \%$ & $69,28 \%$ & $87,99 \%$ \\
\hline
\end{tabular}

40 Supplementary table 1 : Cytometric analysis of the 50 melanoma cell-lines (data are expressed as \% of positive cells) 


\begin{tabular}{l} 
Page 29 of 32 \\
\cline { 2 - 4 }
\end{tabular}

Supplementary table 2 : univariate model for RFS including biomarkers from both untreated and IFN- $\gamma$ treated melanoma celllines (data are expressed as p-values)

\begin{tabular}{|c|c|c|c|c|}
\hline & HR & lower .95 & upper .95 & p-value \\
\hline MCSP & 0.985 & 0.971 & 0.998 & 0.0259 \\
\hline NRAS mutation & 0.506 & 0.245 & 1.045 & 0.0655 \\
\hline Number of invaded nodes & 1.365 & 1.083 & 1.720 & 0.0083 \\
\hline Capsular breaking & 1.824 & 0.875 & 3.804 & 0.1088 \\
\hline
\end{tabular}

Supplementary table 3: Cox model for RFS including only biomarkers from untreated melanoma cell-lines 23

\begin{tabular}{|c|c|c|c|c|}
\hline & HR & lower .95 & upper .95 & p-value \\
\hline MHC class II & 0.986 & 0.968 & 1.004 & 0.1329 \\
\hline MCSP & 0.970 & 0.948 & 0.993 & 0.0099 \\
\hline NY-ESO-1 & 1.035 & 1.015 & 1.056 & 0.0005 \\
\hline tyrosinase & 0.978 & 0.965 & 0.991 & 0.0013 \\
\hline PD-L1 & 1.032 & 1.015 & 1.049 & 0.0001 \\
\hline IDO1 & 1.017 & 1.004 & 1.031 & 0.0130 \\
\hline NRAS & 0.216 & 0.084 & 0.554 & 0.0015 \\
\hline Number of invaded nodes & 1.337 & 1.052 & 0.554 & 0.0175 \\
\hline
\end{tabular}

Supplementary table 4: Cox model for RFS including only biomarkers from IFN- $\gamma$-treated melanoma cell-lines 


\begin{tabular}{|c|c|c|}
\cline { 2 - 3 } \multicolumn{1}{c|}{} & Untreated cell-lines & IFN- $\gamma$ treated cell-lines \\
\hline CMH I & 0,73 & 0,372 \\
\hline CMH II & 0,78 & 0,435 \\
\hline MCSP & 0,212 & 0,543 \\
\hline gp100 & 0,694 & 0,768 \\
\hline Melan-A & 0,201 & 0,147 \\
\hline tyrosinase & 0,0645 & 0,0797 \\
\hline NY-ESO-1 & 0,0439 & 0,331 \\
\hline MAGE-A & 0,00727 & 0,0679 \\
\hline IDO1 & 0,533 & 0,137 \\
\hline PD-L1 & 0,618 & 0,428 \\
\hline
\end{tabular}

Supplementary table 5 : univariate model for OS including biomarkers from both untreated and IFN- $\gamma$ treated melanoma celllines (data are expressed as p-values)

\begin{tabular}{|c|c|c|c|c|}
\hline & HR & lower .95 & upper .95 & p-value \\
\hline tyrosinase & 0.985 & 0.975 & 0.995 & 0.0031 \\
\hline Capsular breaking & 2.476 & 1.126 & 5.444 & 0.0242 \\
\hline
\end{tabular}

Supplementary table 6: Cox model for OS including only biomarkers from untreated melanoma cell-lines

\begin{tabular}{|c|c|c|c|c|}
\hline & HR & lower .95 & upper .95 & p-value \\
\hline MCSP & 0.981 & 0.964 & 0.997 & 0.0201 \\
\hline gp100 & 0.975 & 0.958 & 0.993 & 0.0070 \\
\hline Melan-A & 1.025 & 1.003 & 1.048 & 0.0282 \\
\hline MAGE-A & 0.984 & 0.971 & 0.998 & 0.0230 \\
\hline IDO1 & 1.025 & 1.011 & 1.039 & 0.0005 \\
\hline Breslow & 1.218 & 1.020 & 1.456 & 0.0298 \\
\hline Capsular breaking & 3.656 & 1.575 & 8.491 & 0.0026 \\
\hline
\end{tabular}

Supplementary table 7: Cox model for OS including only biomarkers from IFN- $\gamma$-treated melanoma cell-lines 
Page 31 of $32^{\text {Eventere Survival }}$

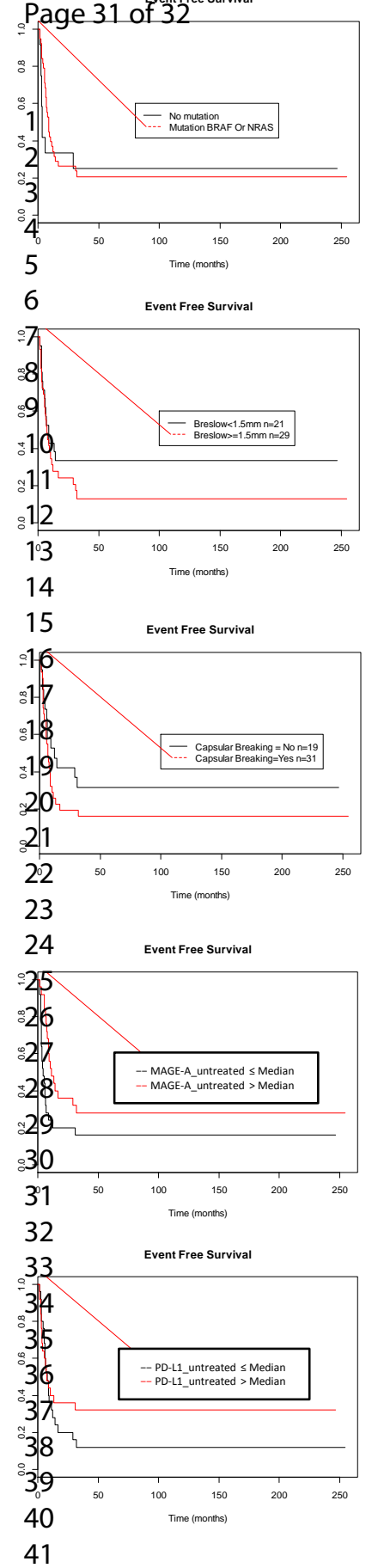

Event Free Survival

Event Free Survival

Event Free Survival
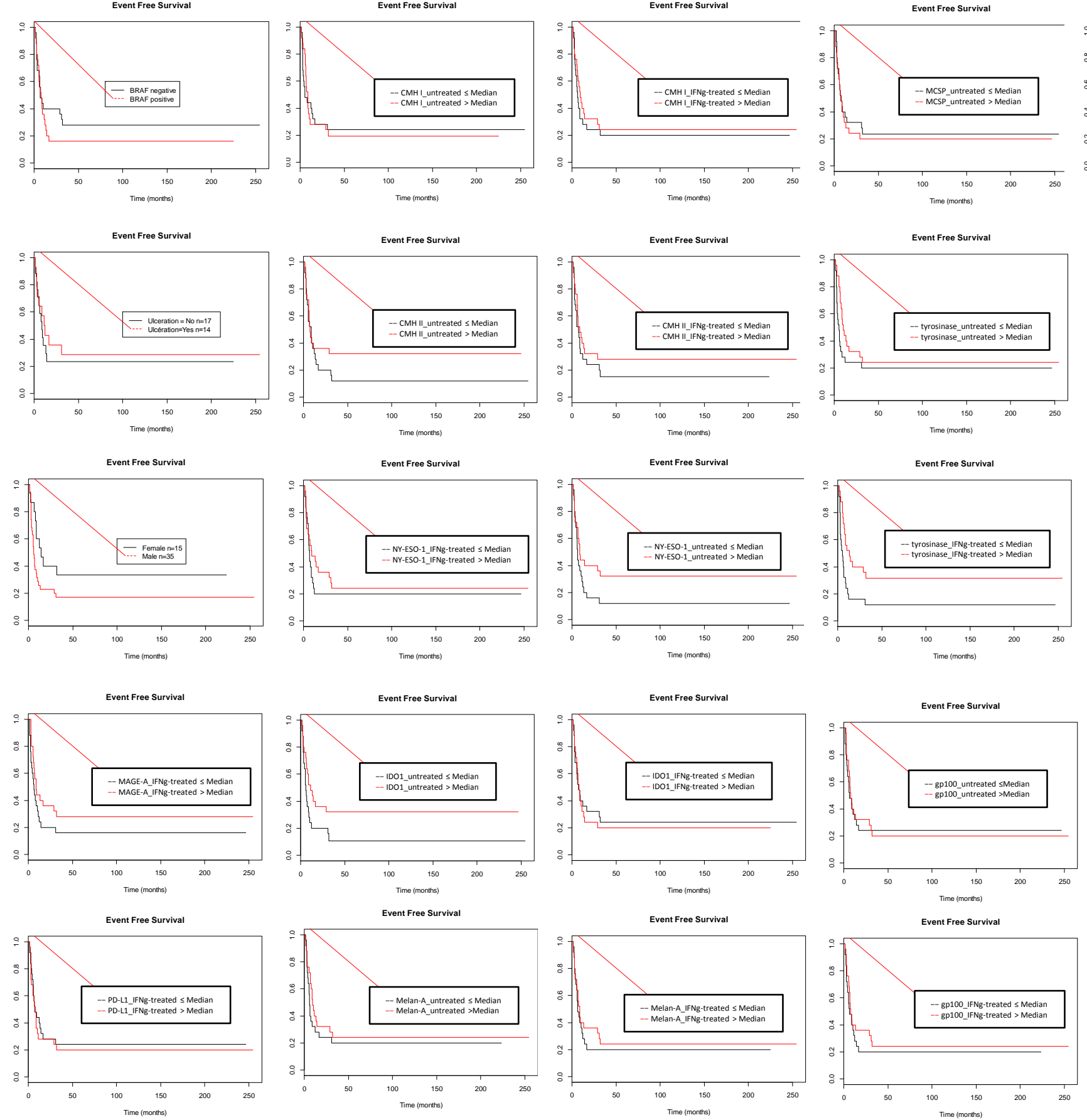

Supplementary figure 1 : Kaplan Meier curves for RFS 


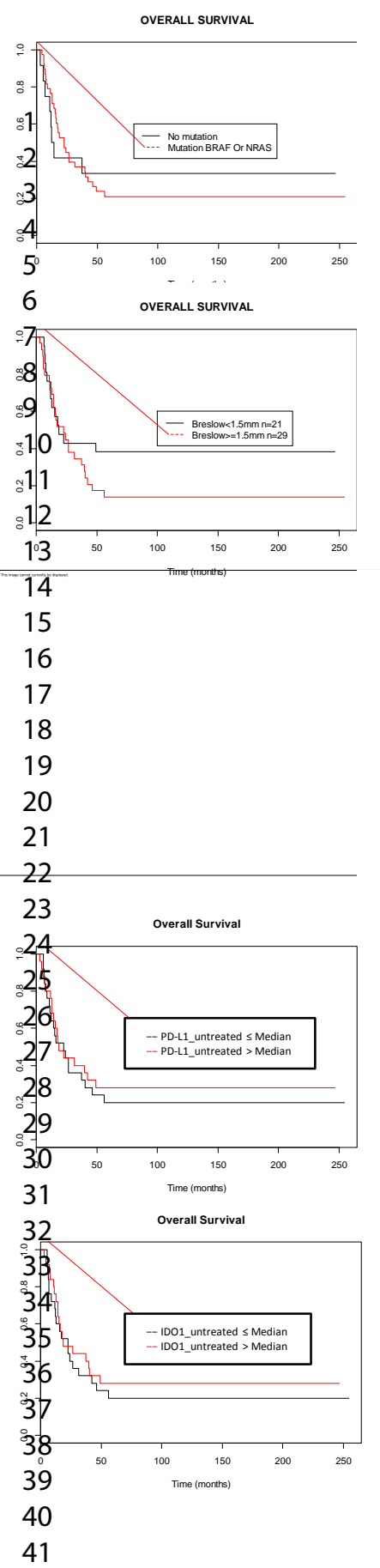

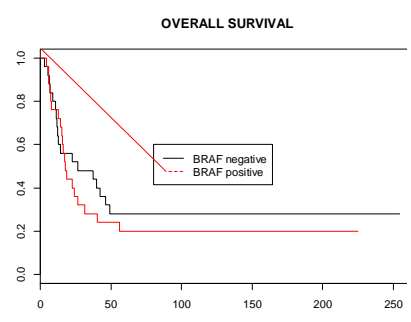

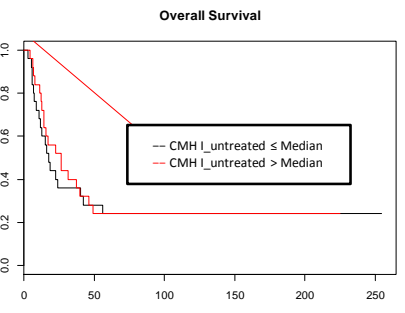

OVERALL SURVIVAL

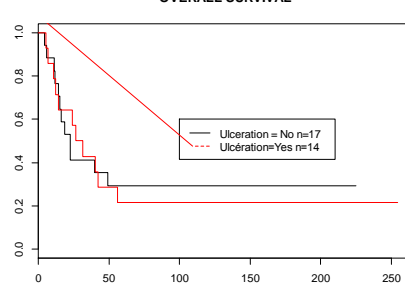

OVERALL SURVIVAL

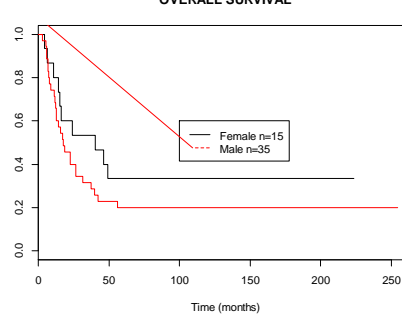

Overall Survival
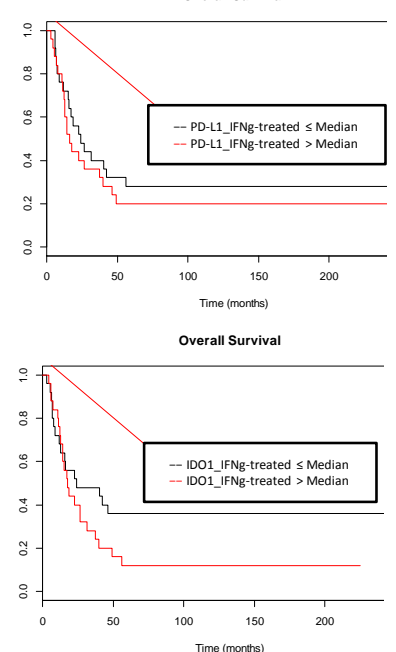

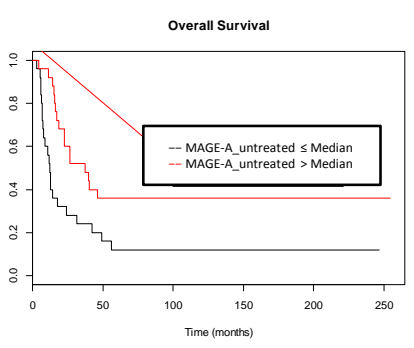

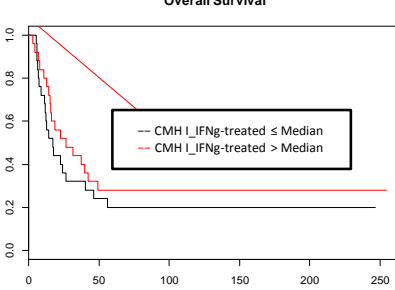

Overall Surviva

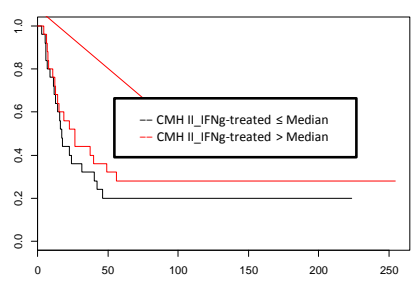

Overall Surviv

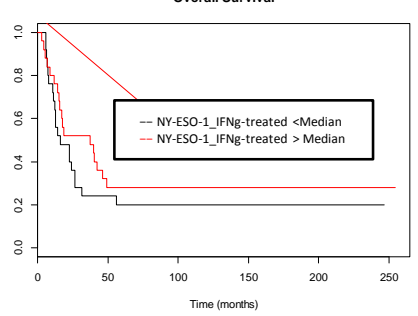

Overall Survival

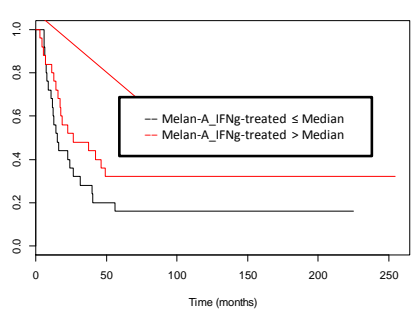

Overall Survival

Overall Survival

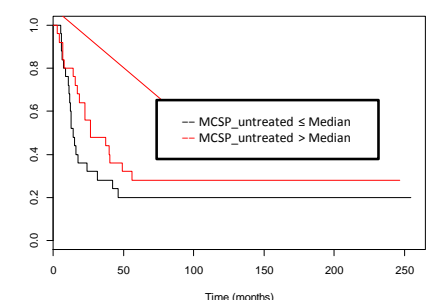

Overall Surviva
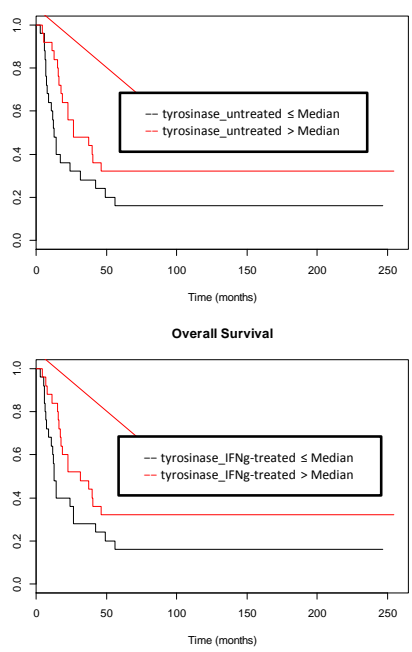

Overall Survival

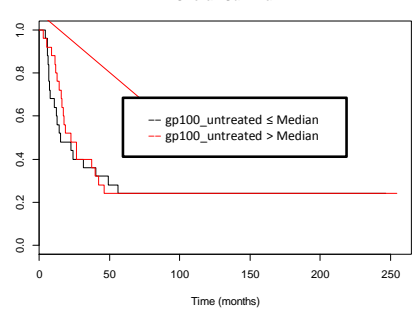

Overall Survival
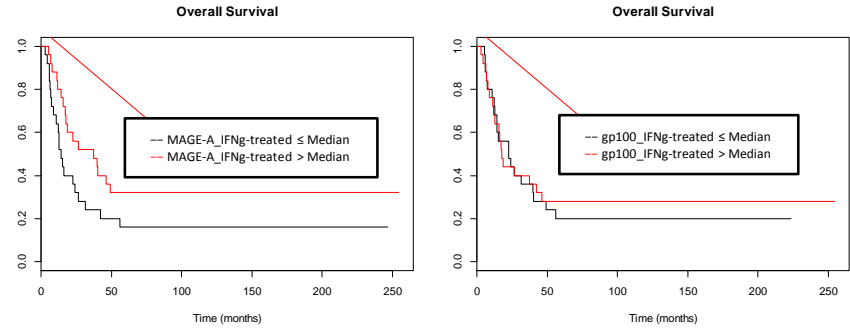

Page 3z: af:32.

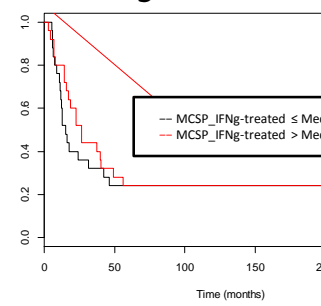

Supplementary figure 2: Kaplan Meier curves for OS 